\title{
Urban greenery for air pollution control: a meta-analysis of current practice, progress, and challenges
}

\author{
Sriroop Chaudhuri ${ }^{(\mathbb{D})}$ Arvaan Kumar
}

Received: 8 August 2021 / Accepted: 22 January 2022 / Published online: 1 March 2022

(C) The Author(s), under exclusive licence to Springer Nature Switzerland AG 2022

\begin{abstract}
Most governmental initiatives in India, to leash down urban air pollution, have yielded little results till date, largely due to purely technocratic vision, which is shrouded by technological, economic, social, institutional, and political hardships. We present this reflective article on urban greenery, as a proposition to urban authorities (e.g., pollution regulators, environmental systems' managers, urban landscape planners, environmental policy makers), shift from purely technocratic way of thinking to thinking with nature, by strategic greening of urban spaces, for long-term air pollution prevention and control measures. To that end, we offer a meta-analysis of recent (post 2005) global literature using four-stage PRISMA (Preferred Reporting Items for Systematic Reviews and Meta-Analyses) approach. We open the narrative by briefing about main pollutant filtration mechanisms by trees, followed by cognitive aspects of species selection (e.g., deciduous vs. evergreen, air pollution tolerance index, environmental stressors). Till date, most Indian studies on urban greenery mostly but focused on
\end{abstract}

Supplementary Information The online version contains supplementary material available at https://doi. org/10.1007/s10661-022-09808-w.

S. Chaudhuri $(\bowtie)$

O.P. Jindal Global University, Sonipat, Haryana 131001, India

e-mail: schaudhuri@jgu.edu.in

\section{A. Kumar}

Global Reporting Initiative (GRI), South Asia, C/O, BSI Group India, Mira Corporate Suites, Plot No. 1 \& 2, Ishwar Nagar, Mathura Road, New Delhi 110065, India e-mail: arvkumarjgu@gmail.com physiological aspects of trees. Here, we draw attention of urban authorities to an equally compelling, but yet less explored, aspect: design criteria, with reference to two most common urban configurations, namely, street canyon and open road. With pictorial depictions, we enumerate various categories of street canyons and discuss aspect ratio (building height to street width) and various wind flow regimes (isolated roughness, wake interface, and skimming), that the urban authorities should be cognizant about to maximize pollutant removal efficiency. For open road, we discuss vegetation barriers, with special emphasis on canopy porosity/density functions. In the final sections, we reflect on a potential systems' thinking approach for on-ground implementation, comprising of revamping of urban forestry programs, research and development, community mobilization and stakeholder engagement, and strategic outreach. In addition, we emphasize on means to harness co-benefits of urban greenery, beyond mere pollutant removal, to garner support from urban residents' communities. Last but not the least, we also caution the urban authorities about the undesirable outcomes of urban greenery that will require more process-level research.

Keywords Urban air quality - Air pollution tolerance index (APTI) - Open road · Street canyon . Aspect ratio - Wind flow regime - Vegetation barrier . Canopy porosity/density $\cdot$ Community mobilization and stakeholder engagement - Outreach and promotion - Dust re-suspension - Biogenic volatile organic compound $(\mathrm{bVOC}) \cdot$ Social/community wellbeing 


\section{Introduction}

Worldwide, air quality-related health hazards are reckoned among the most critical concerns in urban habitats, which calls for strategic detection and monitoring of temporal and regional air pollutant dynamics so as to devise cost-effective remedial measures (Cetin et al., 2019). In India, air pollution has been a perpetual concern to public health (Bera et al., 2020; Ravishankara et al., 2020). A recent assessment titled "Global Burden of Disease Study, 2019," estimated 1.67 million deaths in 2019 (17.8\% of the national total death) owing to air pollution alone, incurring an estimated loss of about USD 36.8 billion $(1.36 \%$ of national GDP) (Basu, 2020). In 2019, 22 Indian cities featured among the global top-30 list of most polluted cities, with several Indian cities occurring in top 10 (IQAir, 2020).

In such backdrop, the COVID-19 lockdown in 2020 offered an unexpected opportunity at environmental re-generation, marked by substantial improvement in urban ambient air quality (Bera et al., 2020; Mahato et al., 2020; Mandal \& Pal, 2020; Sharma et al., 2020). However, it has been a short-lived respite. Young et al. (2021) termed the lockdown as an "anthropause"-rapidly fleeting and unlikely to alter the impact of destructive human activities on long run. Air pollutant levels in many Indian cities began to spike (Kumar \& Chaudhuri, 2021), as soon as lockdown was call off, as have been the case in other world cities (Anjum, 2020; Zowalaty et al., 2020). In several Indian cities, ambient particulate matter levels $\left(\mathrm{PM}_{10}\right)$ have substantially risen through the postun-lockdown periods (Fig. 1), a trend that continued through final quarters of 2020, to become comparable to that of 2019 (life-as-usual situation).

India was hit by the second wave of the COVID19 virus in the current year (2021), surging since February (Gettleman et al., 2021), believed by experts to be more life threatening than its predecessor in 2020 (Faruqui et al., 2021). New Delhi, the capital city of India, re-imposed the lockdown strategy between April 20 and May 30 to restrain disease spread. However, comparison of 24-h ambient PM levels between 2019, 2020, and 2021 (April 20-May 30) indicated little "ameliorative" effect of the current lockdown (Fig. 2). In all the 3 years, both species exceeded the WHO benchmark $\left(10 \mu \mathrm{g} / \mathrm{m}^{-3}\right.$ for $\mathrm{PM}_{10} ; 24 \mu \mathrm{g} / \mathrm{m}^{-3}$ for $\left.\mathrm{PM}_{2.5}\right)$ at all monitoring stations (40 in total), throughout the lockdown period. For $\mathrm{PM}_{10}, 29$ and 21 monitoring stations in New Delhi exceeded the Indian regulatory benchmark $\left(100 \mu \mathrm{g} / \mathrm{m}^{-3}\right)$ in 2021 and 2020, respectively. Ambient air pollution in Delhi, already a long-standing grievance to the urban residents' communities, is comparable to that of Beijing, China (Chaudhuri \& Roy, 2017a), and risks major health calamities in future. A recent assessment to compute Air Quality Health Index (AQHI) for Gurugram City, in state of Haryana in the National Capital Region (NCR), revealed growing risks of pulmonary and cardiovascular risks for children ( $<5$ years) as soon as the SARS-CoV-2 lockdown was lifted in 2020 (Kumar \& Chaudhuri, 2022).

In view of such observations, we aim this reflective article on urban greenery, at the urban air quality regulatory authorities, urban/regional planners and policy makers as a low-cost, nature-based strategy for air quality prevention and control in India. However, efforts of urban air pollution prevention and control in India have paid little dividends, due to purely "technocratic" policy outlook. In developing countries around the world, such approaches have been proven largely ineffective, due to a confluence of institutional, infrastructural, economic, and political barriers (Chen et al., 2017; Gao et al., 2020). As a result, air pollution has continued to threaten environmental sustainability and public health throughout most of India (Chaudhuri \& Roy, 2017a, b, c). Besides the technocratic outlook, another prime reason for the "failure" is that, proposed control solutions, yet overlooks the socio-cultural dimensions: citizens' expectations, capacities, and levels of involvement in the decisionmaking process (Chaudhuri, 2018). With such realizations, a prime impetus to present this narrative was to pave a way: from technocratic way of thinking, to coupled thinking with nature. We urge the policy makers to view urban greenery, as complementary means to diversify and embolden the ongoing initiatives of air pollution prevention and control.

Recent studies have widely expounded on the role of common roadside trees as effective biomonitors of air quality, especially related to traffic-induced heavy metal pollution (Rai, 2016; Sevik et al., 2019). In a recent study in Hatay, Turkey, Sert et al. (2019) observed that rosemary trees can be used as efficient accumulators and biomonitors of a wide variety of heavy metal polluters in ambient air. In a 


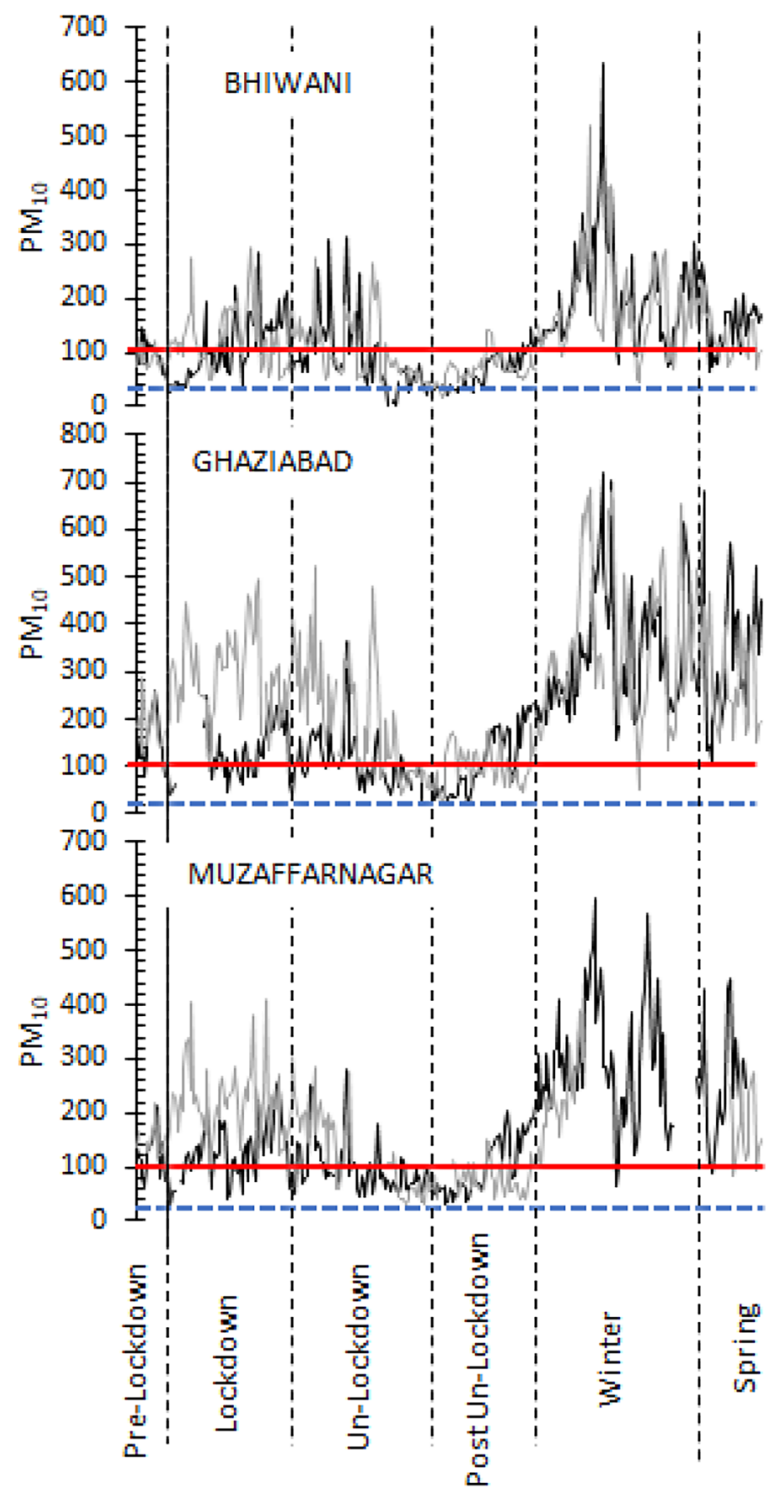

Fig. 1 Comparative assessment of 24-h average concentrations of particulate matter $\left(\mathrm{PM}_{10}\right.$, expressed as $\left.\mu \mathrm{g} \mathrm{m} \mathrm{m}^{-3}\right)$ in six Indian cities, reckoned among 20 most polluted cities worldwide, between 2019, and corresponding time periods in 2020. Note: solid red and blue broken lines, respectively,

study in the Kastmonu Province, Sevik et al. (2020) proposed "edible landscaping"-strategic planting of certain fruit and vegetable trees, such as apple, plum, cherry, and mulberry, which can remove trafficinduced heavy metals (nickel, cobalt) from ambient

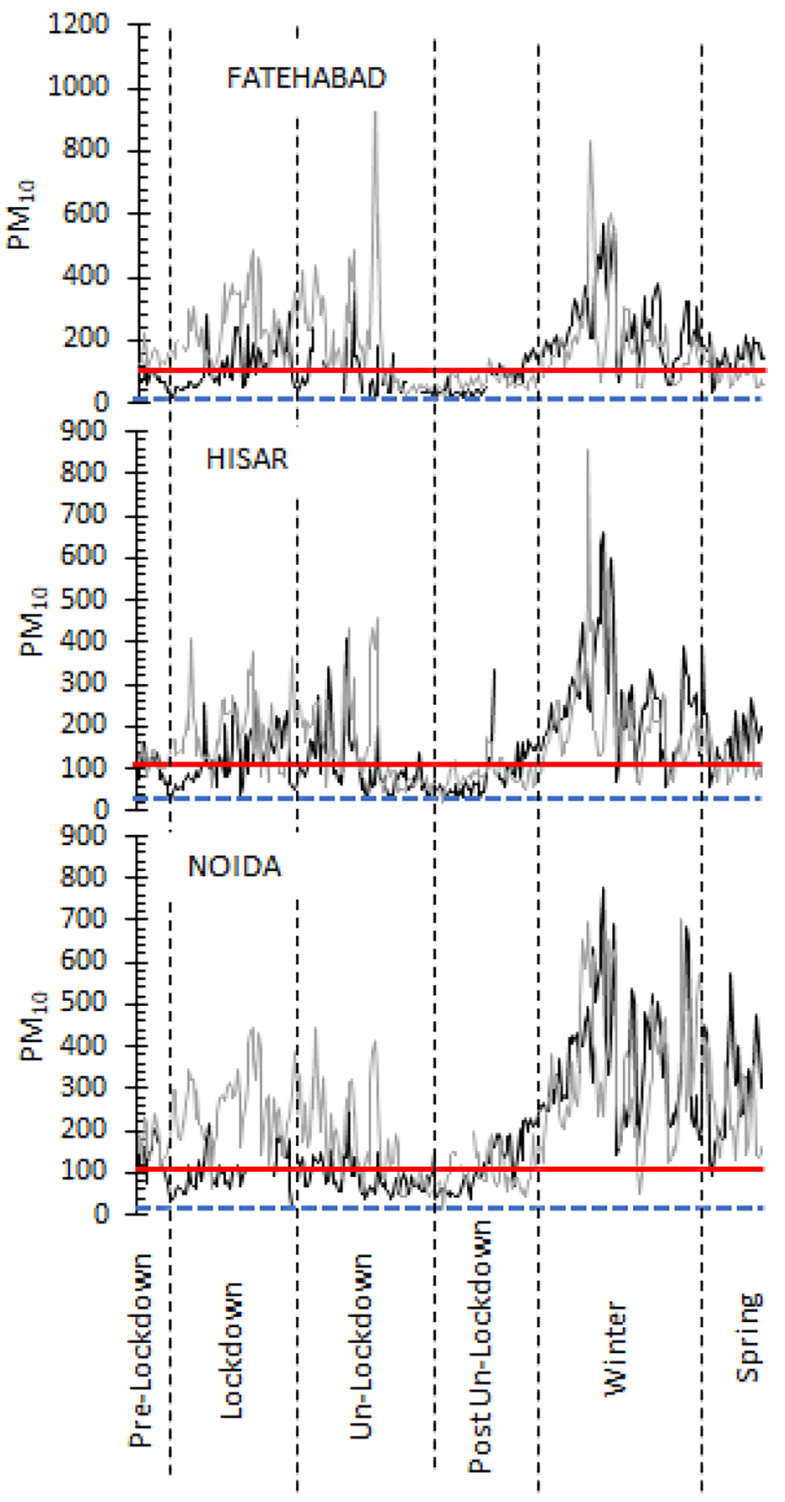

represent the Indian National Ambient Air Quality Standard $\left(100 \mu \mathrm{g} \mathrm{m}^{-3}\right)$ and World Health Organization threshold $\left(10 \mu \mathrm{g} \mathrm{m}^{-3}\right)$ for $\mathrm{PM}_{10}$ (authors' illustration; Data source: Central Pollution Control Board, India)

air. Similar observations are widely reported from Pakistan (Altaf et al., 2020), Malaysia (Silaiman \& Hamza, 2018), China (Qiu et al., 2009), and India (Rahul \& Jain, 2016). In a case study involving traffic-induced heavy metal emissions (zinc, lead, 

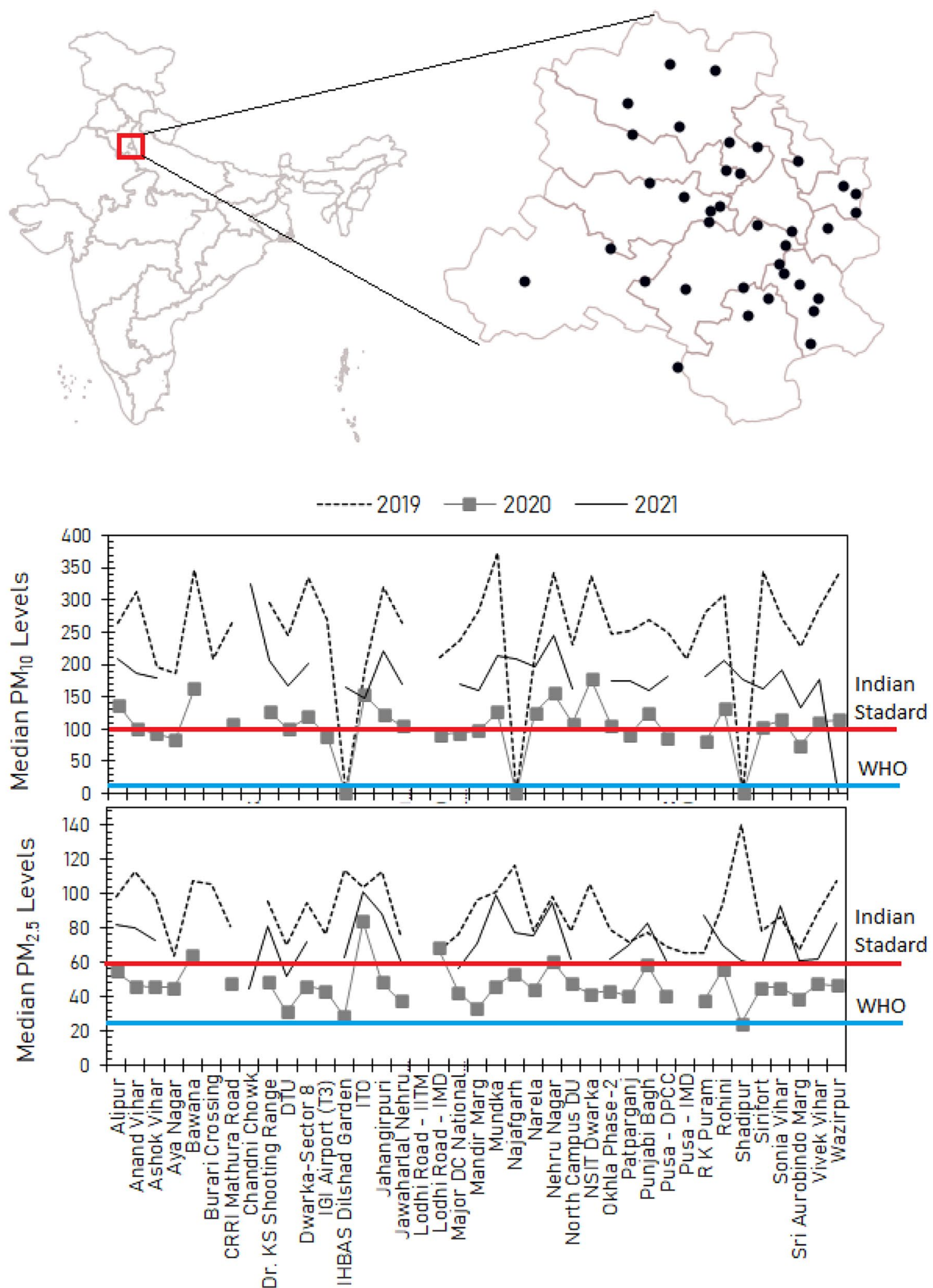
4Fig. 2 Twenty-four-hour median concentrations of $\mathrm{PM}_{10}$ and $\mathrm{PM}_{2.5}\left(\mu \mathrm{g} \mathrm{m}^{-3}\right)$ across 38 air quality monitoring stations in New Delhi between April 20 and May 30 in 2019, 2020, and 2021. Red bold line represents the Indian National Ambient Air Quality Standard $\left(100 \mu \mathrm{g} \mathrm{m}^{-3}\right)$ and World Health Organization threshold $\left(10 \mu \mathrm{g} \mathrm{m}^{-3}\right)$ for $\mathrm{PM}_{10}$. Black circles in the top panel indicate air quality monitoring stations in New Delhi. The blue line represents the Indian National Ambient Air Quality Standard $\left(60 \mu \mathrm{g} \mathrm{m}^{-3}\right)$, and World Health Organization threshold $\left(24 \mu \mathrm{g} \mathrm{m}^{-3}\right)$ for $\mathrm{PM}_{2.5}$ (authors' own illustration; Data source: Central Pollution Control Board, India)

chromium, and copper) in Bangalore City, India, Manjunath and Reddy (2019) observed that plants produced increased phenolic compounds (proline and malonaldehydes) to tolerate and mitigate oxidative stresses of air pollutants.

Use of urban greenery have been widely reported from various Indian cities, including Gandhinagar (Chaudhury \& Rathore, 2018), Vadodara (Patel \& Kumar, 2018), Nagpur (Chaturvedi et al., 2013a), Amritsar (Kaur \& Naapal, 2017), Allahabad (Kuddus et al., 2011), Kolkata (Bera et al., 2020; Ram et al., 2015), and several cities across the National Capital Region (Sharma et al., 2013). Mukherjee and Agrawal (2018) tested 15 tree species in the city of Varanasi, India, and observed that Caesalpinia sappan was the most pollution-tolerant species, followed by Psidium guajava, Dalbergia sissoo, and Albizia lebbeck. Maximum impact of air pollutants was observed on nonenzymatic antioxidants followed by photosynthetic pigments and leaf water status. The authors observed that pollution response of the species were keyed to tree height, canopy dimensions, and foliar morphology, which calls for more process-level research with increased case studies.

However, as Diener and Mudu (2021) observed, "Guidance on green space utilization for air quality control remains scarce, as does its application in practice." In the present narrative, we adopted a universally accepted, systematic meta-analysis namely, PRISMA (Preferred Reporting Items for Systematic Reviews and Meta-Analyses), to present a distillation of current practices, progress, innovations and challenges, to help urban authorities (e.g., pollution regulators, environmental systems' managers, urban landscape planners, environmental policy makers) assess potential merits (and demerits) of urban greenery to complement and bolster ongoing urban air pollution control-abatement initiatives in India. Such review-based meta-analyses have become increasingly popular in policy circle worldwide, because such studies boil down latest innovations around the world, throw lights into potential opportunities and challenges that lay out future research guidelines. Besides, the funding agencies frequently consult such systematic reviews to pinpoint research gaps, identify areas of priority action, long-term benefits of various interventions, and deploy resources accordingly.

We open the narrative with means of tree species selection followed by discussion on key design criteria. In the next section, we propose a systems' thinking approach for the urban authorities: how to revamp existing urban forestry programs; strategically engaging multiple stakeholders, including the urban residents' communities; conduct outreach and promotion. We highlight potential downsides of urban greenery that the urban authorities need to be cautious about. In the final section, we reflect on potential avenues to harness the co-benefits of urban greenery: community wellbeing and eco-environmental.

\section{Methodology}

We undertook a systematic review by identifying most recent (post-2005) global literature, using PRISMA approach (Fig. 3) (Moher et al., 2009; Tomson et al., 2021). The PRISMA method came up among the international research community as an improvement over the previous QUOROM approach (QUality Of Reporting Of Meta-analyses) of literature review (Liberati et al., 2009). PRISMA comprises of a 27-item checklist (view Supplementary Material), within a 4-stage, sequential literature extraction method (Fig. 3). It was the outcome of a 3-day meeting in Ottawa, Canada, in June 2005 with a range of participants, including review authors, methodologists, practitioners, and editors (Moher et al., 2009). Since then, PRISMA has been a preferred method of locating appropriate literature in many recent studies (Liu et al., 2021; Montana et al., 2021; Rowinski \& von Schreeb, 2021), including ones in COVID-19 (Properini et al., 2021). It emerged as response to certain needs: (i) iterative cycle of identifying and reviewing literature; (ii) that conducting and reporting research are distinct concepts; (iii) study-level vs. outcome-level assessment of risk of bias; and (iv) importance of reporting biases. 
Fig. 3 Simplified schematic of the four-stage sequential literature extraction procedure using PRISMA (Preferred Reporting Items for Systematic Reviews and MetaAnalyses) (authors' own illustration)
STAGE I: Initial Search

Documents retrieved using database searching

Total number of documents: 293

Total documents not complying with the rules: 154

Total Documents not meeting the criteria: 13

\section{Documents assessed based on various requirements (details given in the text)}

STAGE II: Setting the Screening Rules

Documents excluded due to various reasons (detailed in text)

\section{STAGE III: Setting the Eligibility Criteria}

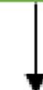

STAGE IV: Final Inclusion

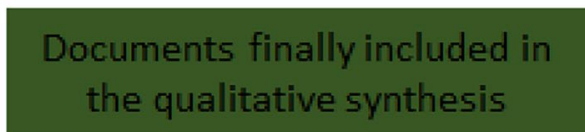

Total Documents retained and included in the study: 126
In the present context, the literature search was performed across various portals including SCOPUS, PubMed, Science Direct, Springer Link, Blackwell and Social Citation Index, Web of Science (WoS), EconLit, JSTOR, and Google Scholar. The search included peer-reviewed manuscripts, working papers, white papers, dissertations, book chapters, and gray literature. In the initial stage, following words/phrases were used to retrieve documents: "urban greenery"; "air pollution"; "air pollut*”; "air qual*”; "particulate matter"; "PM10"; "PM2.5"; "PM*"; "urban", "vegetation barrier"; "street canyon"; "aspect ratio"; "green barrier"; "open road"; "disperse*", "deposit*"; "wind flow"; "vortex". Search words and phrases were combined in various permutation combinations. Each search phrase and/or word was preceded and/or succeeded by "urban" and/or "city." The asterisk symbol ("*”) was used as wildcard to expand the search horizon. Retrieved documents included peer-reviewed manuscripts, book chapters, technical documents, white papers, thesis, dissertations, and gray literature.
In the initial stage, we identified a total of 293 documents. In the second stage of PRISMA, documents were screened following a procedure (Chaudhuri et al., 2020a, 2021a, b):

- Documents with duplication of results (51 documents excluded)

- Abstract-only, full-text documents unavailable (34 documents)

- Studies that have too many confounding variables (29 documents)

- Studies published before 2005 (18 documents)

- Studies not published in English language (22 documents)

In the third stage, documents retained from the second stage of PRISMA were subject to a set of "eligibility" criteria:

- Studies with objective(s) well-aligned with the present study 
- High quality of physiographic traits and/or design criteria (process-level insights)

- Reasonable enumeration of impacts (urban sustainability and/or public health)

- At least brief mention of challenges and future opportunities

At the final stage, a total of 126 documents were short-listed to be included in the study.

\section{Results}

Main pollutant removal mechanisms

Interactions between foliar surfaces and pollutants can be grouped into two broad categories:

Stomatal uptake It involves removal of air pollutants (e.g., ozone, $\mathrm{NO}_{\mathrm{x}}$, and $\mathrm{SO}_{\mathrm{x}}$ ) by gaseous diffusion of into inner part of leaves (Nowak et al., 2013). After getting inside the leaves, the gases diffuse into intercellular spaces where they are generally absorbed by water films to form acids (Avni \& Chaudhry, 2016).

Dry deposition It denotes the processes of removal of pollutants, via leaf interception during non-precipitation period (Selmi et al., 2016). This owes to large surface area of trees per unit volume, as compared to smooth, manufactured surfaces (e.g., cement, concrete, stones, metals) (Janhall, 2015). Deposition of sub-micrometer particles on synthetic grass is about 10-30 times faster than that on glass and cement surfaces (Roupsard et al., 2013).

Process-level understanding of dry deposition is yet challenging. In a very simplistic approximation, dry deposition occurs via (Giardina et al., 2019):

- Transport due to atmospheric turbulence in the lower part of the planetary boundary layer (PBL), also called the Surface Layer (SL), depending on the atmospheric turbulence. Dry deposition is more effective in turbulent wind flow regime (due to friction velocity) (Rai, 2016).

- Diffusion in thin layer of air, which overlooks the air-ground interface (named quasi-laminar sublayer, QLS), where the molecular diffusion for gas, Brownian motion and turbulent diffusion for particles and gravity for heavier particles become dominant.

- Transfer to the ground (interception, impaction, rebound), dependent on the foliar surface types.

In a recent bibliometric analysis, Diener and Mudu (2021) have divided main plant-mediated pollutant removal mechanisms, with respect to public health risks, into three main categories: (I) dry deposition, (II) dispersion (how plants change the trajectory and velocity of air pollutants through their physical structure), and (III) modification (comprising of three mechanisms: selective sorption, microbiological reaction, chemical coagulation ensuing from Brownian motion and/or van der Waals forces). We urge the urban authorities to consult such literature to understand mechanistic details of plant-pollutant interactions and to optimize use of urban greenery. However, as urban canopy represents a wide diversity of foliar surface types, mechanistic understanding of dry deposition process is confounded by many variables, especially when it comes to movement of submicronsized particles. By the same token, there is yet dearth of experimental data covering all possible scenarios involving dry deposition (Giardina et al., 2019). The complexity increases with level of urban development, sources of pollutants, and anthropogenic activities, which will take increased cased studies, in different urban habitats and population characteristics, to ideate dry deposition processes. In the least, the urban authorities should be cognizant of certain factors, including:

- Pollutant characteristics (concentrations; types; gaseous and/or particulate; particle density and diameter) (Roupsard et al., 2013)

- Leaf area (Wang et al., 2015) and leaf micromorphology (presence of wax layers and trichomes) (Shao et al., 2019)

- Ambient weather conditions (Schaubroeck et al., 2014)

Tree species selection

\section{Deciduous vs. evergreen?}

Initial clue to tree species selection should be climatic trait and how it influences length growing season 
(duration of foliar cover available) (Cetin et al., 2018; Pace \& Grote, 2020; Popek et al., 2013; Przybysz et al., 2019). In temperate climates, deciduous varieties shed leaves in winter, thus reducing total available foliar surfaces for pollutant removal. Among the deciduous varieties, conifers are often preferred for pollutant removal due to, presence of lipophilic wax layers on needles, smaller leaves, and complex shoot structures (Chen et al., 2017). Moreover, wind flow across conifer needles is more turbulent than across large plates (broadleaves), leading to the reduced boundary layer thickness of needle leaves. (Ackerly et al., 2002; Pace \& Grote, 2020). When pollutantladen air travels across the needles, the boundary layer stays relatively stationary and forms a barrier between the surrounding air and the leaf surface.

However, excessive pollutant capture by coniferous needles may eventually cause damage to foliar structures, reducing pollutant removal efficiency. Such cases are more apparent in drier latitudes (Pace \& Grote, 2020). Under such circumstances, broadleaved deciduous species, or species that retain foliage throughout winter, should be selected for regulatory purposes (Przybysz et al., 2019). Among broadleaved varieties with high (i) number of grooves, (ii) groove ratio (groove area/total leaf area), and (iii) epicuticular trichome density should be preferably selected for regulatory purposes (Chen et al., 2017).

However, in climatic zones where the growing season is shorter, but have high pollutant levels during winter, evergreen varieties, whose foliage is available year-round, should be preferred to deciduous varieties (Mori et al., 2018). Species selection should also be guided by target pollutant types. For example, Nicola et al. (2017) observed that oak leaves (deciduous) are better for particulate phase PAH (polycyclic aromatic hydrocarbons), probably due to high specific leaf area. On the other hand, for gaseous phase $\mathrm{PAH}$, pine needles (evergreen) could be more suitable. The latter are ideal for capturing low and medium molecular weight PAHs.

\section{Index-based decision making?}

The air quality regulatory authorities might also look into quantitative means, such as air pollution tolerance index (APTI), which has already been attempted in various Indian cities (Dwivedi \& Tripathi, 2007;
Kaur \& Nagpal, 2017; Panda et al., 2018; Sen et al., 2017; Yadav \& Pandey, 2020) to identify tree species more objectively. The APTI is determined by the following equation:

$$
\mathrm{APTI}=\frac{[\mathrm{A}(\mathrm{TChl}+\mathrm{P}]+\mathrm{R}}{10}
$$

where
A: Ascorbic acid content $\left(\mathrm{mg} \mathrm{g}^{-1}\right)$
TChl: Total chlorophyll content $\left(\mathrm{mg} \mathrm{g}^{-1}\right.$; indica- tor of impact of air pollutants on photosynthetic activities)
$\mathrm{P}$ : Leaf extract $\mathrm{pH}$ (indicator of development of detoxification mechanism in plants necessary for tolerance)
R: Relative water content (moisture holding capac- ity of a plant; indicative of the hydration condi- tions in the leaf matrix).

In the APTI expression, ascorbic acid content appears the most effective indicator of air pollution. Ascorbic acid provides stability to cell membranes against pollution stress, and offers resistance to adverse climatic conditions. Moreover, it decreasing reactive oxygen species in leaves and saves thylakoid membrane from oxidative damage. Air pollution causes denaturation of chloroplast, marked by decline pigment contents in the cells of polluted leaves. Comparing between industrial and nonindustrial sites in India, Rai et al. (2013) observed significantly higher ATPI signature of industrial sites, due to elevated emission levels. Zhang et al. (2016) computed APTI for 47 plant species in suburban Beijing to identify species such as Magnolia denudata, Diospyros kaki, Ailanthus altissima, Fraxinus chinensis, and Rosa chinensis as most suitable for heavily trafficked conditions.

For regulatory purposes, the APTI could also be integrated with a range of biological and socioeconomic factors to develop a grading scheme for selecting ideal plant varieties (Table 1). Species with higher APTI values are deemed ideal for pollutant removal, while those with relatively lower APTI values might be considered for bio-indicators of ambient air pollution. Some studies also proposed an extension of APTI, the anticipated performance index (API), that assigns performance-based 
numerical scores to plants and considered ideal for "green belt" development in industrial areas (Table 2) (Gupta et al., 2016a, b; Irshad et al., 2020; Yadav \& Pandey, 2020).

\section{Environmental stressors and species sustainability}

Authorities have to be mindful about environmental stressors that negatively impact sustainability of urban greenery, thus reducing pollutant removal efficiency (Mullaney et al., 2015; Roman et al., 2014; Sjöman et al., 2016). Of particular importance are soil hydrology, nutrient contents, tree rooting conditions, pest attacks, restrictions for tree crown growth, to name a few. Authorities should also be careful about drought events, which could downscale pollutant removal efficiency by limiting gas exchange at the leaf surface (Hirabayashi \& Nowak, 2016). Additional factors

Table 1 Grading scheme of plant species based on air pollution tolerance index (APTI) and different biological parameters and socio-economic importance (for each grading consideration and category, higher the number of "+" signs, more suit-
Table 2 Gradations of anticipated performance index (API) of plant species. "Score" of each plant species in consideration is computed by taking the percentage of sum total of the "+" signs it gets from Table 1

\begin{tabular}{lll}
\hline Grade & Score $(\%)$ & Plant species \\
\hline 0 & $<30$ & Not recommended \\
1 & $31-40$ & Very poor \\
2 & $41-50$ & Poor \\
3 & $51-60$ & Moderate \\
4 & $61-670$ & Good \\
5 & $71-80$ & Very good \\
6 & $81-90$ & Excellent \\
7 & $>90$ & Best \\
\hline
\end{tabular}

include unplanned development (built topography) rapid growth of physical infrastructure, which introduces heterogeneity in ground conditions and creates micro-climates at local scale.

able it is for air pollution prevention and control; tree species with high cumulative "+" values are preferable for regulatory purposes)

\begin{tabular}{|c|c|c|c|}
\hline \multicolumn{2}{|l|}{ Grading considerations } & \multirow{2}{*}{$\frac{\text { Category }}{9.0-12.0}$} & \multirow{2}{*}{$\frac{\text { Grade allotted }}{+}$} \\
\hline Tolerance & APTI & & \\
\hline & & $12.1-15.0$ & ++ \\
\hline & & $15.1-18.0$ & +++ \\
\hline & & $18.1-21.0$ & ++++ \\
\hline & & $>21.1$ & +++++ \\
\hline \multirow[t]{8}{*}{ Biological and socioeconomic } & Plant habit & Small & - \\
\hline & & Medium & + \\
\hline & & Large & ++ \\
\hline & Canopy structure & Sparse/irregular/globular & - \\
\hline & & Spreading crown/open/semi-dense & + \\
\hline & & Spreading dense & ++ \\
\hline & Plant type & Deciduous & - \\
\hline & & Evergreen & + \\
\hline \multirow[t]{10}{*}{ Laminar structure } & Size & Small & - \\
\hline & & Medium & + \\
\hline & & Large & ++ \\
\hline & Texture & Smooth & - \\
\hline & & Coriaceous & + \\
\hline & Hardiness & Delineate & - \\
\hline & & Hardy & + \\
\hline & Economic value & $<3$ uses & - \\
\hline & & $3-4$ uses & + \\
\hline & & $>5$ uses & ++ \\
\hline
\end{tabular}


Among other atmospheric variables, a critical element to watch out for could be the potential impacts of UV-B radiations on health of various tree species, as recent observations indicate potential concerns regarding germination and retarded seedling development (Ozel et al., 2021). This calls for more targeted research, using site-specific parameter (anthropogenic practices), and management history (socio-demographic correlates).

\section{Design criteria}

Once decided upon tree species, the air quality regulatory authorities and urban landscape planners should be mindful of two main geometric configurations (Abhijith et al., 2017; Hewitt et al., 2019; Tong et al., 2016).

I. Street canyons: Buildings on both flanks of the street.

II. Open roads: Roads open on both flanks with detached, single-/multi-story buildings and/or other manmade structures.

\section{Street canyon}

Street canyons are critical to the air quality regulatory authorities because of (i) greater exposure risk of air pollutants at pedestrian height (breathing level) and (ii) pollutant levels within street canyons which are higher than the urban background (Zhong et al., 2016). Street canyons present a semi-enclosed environment, within which emissions are entrained in a re-circulatory system, with reduced opportunities for natural ventilation (pollutant dilution) (Janhall, 2015). Effective pollutant removal strategies within street canyons should take into account (1) wind regime (velocity, direction, vortex); (2) aspect ratio, (3) vehicular traffic, and (4) tree stand density:

Wind velocity Reduced wind velocities generally leads to a surge in pollutant load in street canyons due to poor ventilation (Hofmann \& Samson, 2014), which is aggravated during winter.

Wind direction There could be two main situations (Abhijith et al., 2017; Gromke \& Ruck, 2012).
- Perpendicular wind direction $\left(90^{\circ}\right)$ : Free-stream wind flow is perpendicular to the main street axis. Such flow directions can lead to both higher and lower pollutant concentrations, respectively, along the leeward and windward side of the canyon hat will require more process-level research with increased case studies. In general, with perpendicular wind flow, the roof-level background atmospheric flow can create re-circulations in the street canyons. These re-circulations lead to relatively calmer wind flow at ground level (where receptors and pollutant sources coexist), reduces ventilation, and thus, lowers chances of pollutant dilution (more concentrated pollutant loads).

- Oblique $\left(45^{\circ}\right)$ and parallel $\left(0^{\circ}\right)$ : Increase in pollutant levels on both sides, along with increasing pollutant concentrations towards the outer end of the canyon.

Aspect ratio (building height/street width; H/W) It affects pollutant dispersion by creating local airflow patterns (Zhong et al., 2016). Street canyons can be classified by ratio between buildings height $(\mathrm{H})$, and street width (W) (Fig. 4) (Yazid et al., 2014). Regulatory authorities should pay special heed to deep canyons (urban areas where $\mathrm{H} / \mathrm{W} \geq 2$ ), which generally have higher pollutant loadings (lower ventilation opportunities) than the shallow canyons $(\mathrm{H} / \mathrm{W} \leq 0.50)$. It largely owes to the fact that, as canyon depth increases, the primary wind vortex gradually gets split into multiple parts (discussed more in details later), which generally reduces pollutant removal capacity of trees. $\mathrm{Li}$ et al. (2020b) observed significant differences in pollutant dynamics between step-up and step-down street canyons. For step-up canyons, upwind buildings with higher aspect ratios are expected to experience warmer temperatures and thus accumulate higher pollutant loadings irrespective of wind speeds, as compared to its upwind buildings with lower aspect ratios. In contrast, for the step-down canyons, downwind buildings with higher aspect ratios generally experience cooler air temperatures at both high and low wind speeds and accumulate more pollutants only at a low wind speed, compared with downwind buildings with lower aspect ratio.

Wind vortex Pollutant dispersion in street canyons mainly results from creation of different types of wind vortexes (Fig. 5a) which can be grouped into three broad categories based on $\mathrm{H} / \mathrm{W}$ ratio (Fig. 5b) 
(Oke, 1988): (i) isolated roughness flow (IRF),: widely spaced building in shallow canyons with $\mathrm{H} / \mathrm{W}<0.30$ ); (ii) wake-interference flow (WIF): occurs in canyons with tightly packed building $(0.30<\mathrm{H} / \mathrm{W}<0.070)$; and (iii) skimming flow (SF), generally occurs in deeper canyons, with more tightly spaced building (smaller "W" values than in WIF), and leads to poorest air quality.

Wind vortexes may also be influenced by "microroughness" elements, such as balcony depth and horizontal separation between two balconies (Murena \& Mele, 2016). It is more apparent in deep street canyons, where balconies lead to heterogeneity in pollutant dispersion mode, with lower effective mass exchange with the atmosphere above. Urban planners are to understand such possibilities to improve façade designs to curb risks of pollutant entrapment.

Vehicular traffic Understanding potential impacts of vehicular movement on the airflow is critical to construct effective urban greenery (Carpentieri et al., 2011; Yazid et al., 2014). Ahmed et al. (2008) advocated for more one-way traffic conditions, which results in "piston-like" effects within street canyon, to disperse air pollutants, thus improving ambient air quality. At process level, moving vehicles induces turbulence that leads to 'atmospheric mixing', both at micro- and macro-scale (Solazzo et al., 2008). The latter leads to advective transport of pollutants, which entrains masses of air in the direction of vehicle motion. As a rule of thumb, regulatory authorities should remember that, greater the turbulence, lesser the likelihood of air and pollutant stagnation near ground surface, and lower the threats to public health.

Tree stand density This denotes the cross-sectional area covered by tree stands and more critical in shallow street canyons ( $\mathrm{Ng} \& \mathrm{Chau}, 2012)$. Increasing the spacing between tree crowns and/or lowering their cross-sectional areas can decrease pollutant concentrations in street canyons (Abhijith \& Gokhale, 2015).

\section{Open road}

Past studies have proposed vegetation barriers for open road geometry, which have demonstrated $\mathrm{PM}_{10}$ removal efficiencies (Tiwary et al., 2008).
For effective construction of vegetation barriers, Baldauf (2017) emphasized on three critical design elements: (i) height (preferably $>5 \mathrm{~m}$ ), (ii) thickness (>10 m), and (iii) porosity (tree/foliar density). Most critical among the above is the porosity parameter, which needs to be "optimized" with respect to local biophysical and anthropogenic traits (Gromke $\&$ Blocken, 2015). The main idea is that vegetation barriers should not be too porous such that the pollutants easily filter through (Tiwary et al., 2005). However, the barriers should not be too dense either so as to create an "impermeable" wall, in which case, pollutant-laden air is forced up and around the plants, without being filtered (Mori et al., 2018). Such conditions may lead to (i) "recirculation" of wind (and pollutants) behind the barrier, and (ii) separation of air below the canopy from that of the above, thus creating differential pollutant loadings (vertical gradation) (Baldauf, 2017).

In urban habitats where ground-level air pollution sources are scarce, but has dense vegetation canopies (e.g., parks), below-canopy air is generally cleaner than above-canopy air, due to higher deposition on foliage as air percolates through canopy (Hewitt et al., 2019). However, when canopy closure occurs in places with high ground-level pollution, pollutants may be entrapped, leading to increased groundlevel pollutant concentrations (Abhijith et al., 2017). In such situations, the air quality regulatory authorities, in collaboration with city planners, should install local emission control measures in sync with urban greenery. To that end, optimization of barrier porosity will require carefully designed post-planting vegetation management as per local traits, such as thinning of high-density hedges (Barwise \& Kumar, 2020).

\section{Discussion}

On-ground implementation: a systems' thinking?

Besides other health impacts, inherently poor urban air quality can accentuate SARS-CoV-2 virus spread in multiple ways in many Indian cities. For example, elevated particulate matter levels can trigger cellular inflammation, generate free radicals, that affect and weaken lung functions (Lodovici \& Bigagli, 2011); increase the SARS-CoV-2 virus susceptibility by stimulating a receptor (ACE-2) on cell surfaces 
(Brake et al., 2020); and extend the longevity of the viral particle load in the air (Frontera et al., 2020).

Under the circumstances, strategically established, and carefully maintained, urban greenery can complement and embolden the ongoing air pollution prevention-abatement initiatives on long-term basis. However, in the present standing, availability of urban green spaces in India is far from what is desired (Fig. 6). For example, by 2017 estimates, per capita green cover in most Indian cities is below the nationally recommended standard $\left(9 \mathrm{~m}^{2} /\right.$ person), and substantially below the US and European standards (20 $\mathrm{m}^{2} /$ person) (Fig. 6a). Moreover, in four major metropolitan hubs of country, including the capital city New Delhi, per capita urban green cover is several orders of magnitude lower than that of the world cities with comparable population (Fig. 6b). Even, city area-wise percentages of urban green cover is substantially lower in India, compared to most world cities (Fig. 6c).

Under the circumstances, introducing and integrating the idea of urban green spaces in the mainframe urban sustainability program will require proactive efforts on behalf of all concerned authorities to create an ecosystem of actors who are able to participate in and meaningfully contribute to the initiative. It calls for an integrated vision, a conscious deliberation on behalf of the urban authorities, to seamlessly integrate the scientific, technological, financial, social, and institutional dimensions of urban/regional planning, and an ecosystem of actors within a participatory arrangement (Fig. 7).

To that end, we urge the urban authorities to adopt a systems' thinking approach around following themes, in the least:

(A) Re-vamping existing urban afforestation programs: The governing idea is to include the idea of urban greenery in the mainstream urban/ regional planning right from the outset (in case of newly proposed urban habitats, smart cities), and integrate urban greenery with other sustainability initiatives, especially the economic development agenda, as possible/relevant (realistic situation):

- Allotment of land for urban greenery to be determined by active stakeholder consultation (interviews, focused group discussions, meetings, campaigns)
- Whether land is conserved or developed could be justified based on the economic value of tree canopies on house prices

- Allocate designated land to urban forestry programs and protect them from other land uses with strictly punishable legal clauses.

- Development of land location protocols based on land constraints-new urban development plans, financial capacity to maintain trees in healthy conditions, urban neighbor hood characteristics.

- Use of recycled wastewater to maintain urban greenery, especially for regions with water scarcity. However, regulatory authorities have to perform full-scale assessment to optimize application rates of recycled water/municipal solid waste based on:

- Local meteorology: temperature, precipitation, relative humidity, frequency and intensity of rainfall, rate of evapotranspiration

- Local hydrogeology: topography, slope and aspect, rock formations, geologic structures, rate of infiltration and runoff (proportion of built area)

- Soil properties: conductivity, structure and texture, organic matter contents, and urban development (proportion of built area)

In addition, the authorities should be mindful about (i) maintaining environmental health standards, (ii) esthetic qualities (e.g., odorfree water), and (iii) social taboos of recycled water.

(B) Prioritizing action in crises areas (air pollution hot spots): Areas of prime concern are the sites of active emission with high exposure risks. It will comprise of the following (Fig. 8):

- Identifying initial targets (time-bound goals for pollution reduction)

- Conducting interdisciplinary research, using local information and residents' inputs, to understand systems' requirements 
- Identify viable targets (realistic pollution reduction benchmarks)

- Optimize cost-effective strategy

A critical need is to ideate the main pollution hotspots, for which, recent studies have advocated spatial mapping including coupled use of geographic information system (GIS) and various remote sensing technologies (Cetin, 2015a, b; Ortakavak et al., 2020). To that end, we urge the urban air quality regulators and city planners to be cognizant of certain possibilities:

- Greenbelts: in and around industrial areas

- Green oases: in poorly ventilated areas

- Green wall/roofs, and greening of parking lots (any open and available space) in densely populated, low-income neighborhoods

- Wetlands: establishing new ones while rejuvenation of existing ones

Barwise and Kumar (2020) outlined a comparative summary of preferences for tree species in open road vis-à-vis street canyons that may provide the urban authorities initial clues to probe into the matter (Table 3).

(C) Building a participatory framework: The idea is to strategically engage, enable, and empower urban residents' communities to participate in, and contribute to, the green initiatives. Their involvement should range from tree species identification, to site selection, to construction design, to maintenance and monitoring of greenery. This will increase the level of acceptance of the initiative. However, this calls for patience and right mindset; the authorities should realize that it is a time consuming, and iterative process, as not all hardships/shortcomings could be envisioned and resolved beforehand. Following measures should be considered:

- Formation of a steering committee and grievance redressal cell:

- Members to both bodies should be democratically elected and chaired by a retired district magistrate or high-court judge with apolitical views.

- The steering committee should also help the urban authorities identify viable stakeholders to support the initiative; this can occur by one-onone meetings, presentations, focused group discussions, online/telephonic conferences.

- Strategic technical support to maintain urban greenery in a functional state:

- Besides regular extension support by government agencies, urban authorities may also consider to train and equip a small group of environmentallymotivated urban residents who are well connected in the community to influence positive changes and attract others into the action framework.

- Providing hassle-free, financial packages to those who want to take up green initiatives at home:

- Bank loans with low interest rates.

- Performance-based incentives for all who want to participate in, contribute to, green initiatives (e.g., tax rebates).

- Developing step-by-step instruction manuals for green roofs and/or vertical gardens. The manuals should be written in local dialect and not burdened with technical jargons.

- Urban authorities should facilitate formation of a functional information network (phone apps, social media platforms) among the interested parties, including urban residents, so as to ensure smooth disseminate ideas, data, techniques, best practices, and attract individuals from the community. Research shows that participants in a project feel more comfortable learning from co-participants than officially designated instructors (Chaudhuri et al., 2020a, b, c).

A prime motivation to devise a full-proof community mobilization plan, so as to avoid unintended negative outcomes of urban greenery, such as:

- Conflict between various users and competition for space, especially for rapidly sprawling urban habitats, growing proportions of slums

- Degradation of urban green spaces due to unsustainable use

- Community dissatisfaction with green space features/services 
Table 3 Critical consideration for the selecting vegetation types for open roads and street canyons

\begin{tabular}{|c|c|c|}
\hline & Open road & Street canyon \\
\hline $\begin{array}{l}\text { High-level vegetation } \\
\text { (trees, with a canopy lifted from the } \\
\text { ground level) }\end{array}$ & $\begin{array}{l}\text { - Improves pedestrian-side air quality } \\
\text { when planted as vegetation barrier (woody } \\
\text { plants preferable) } \\
\text { - Pollutant removal efficiency depend } \\
\text { on wind dynamics, temperature, relative } \\
\text { humidity, position and physical } \\
\text { characteristics of green barrier } \\
\text { - Tall and dense (low-porosity) vegetation } \\
\text { recommended } \\
\text { - Small gaps or breaks in barrier } \\
\text { - Barrier thickness should be maximized } \\
\text { across space available } \\
\text { - Barrier length to extend beyond area } \\
\text { of concern }\end{array}$ & $\begin{array}{l}\text { - Pollutant dispersion tied to aspect ratio } \\
\text { and local wind dynamics } \\
\text { - Generally detrimental irrespective of } \\
\text { configuration } \\
\text { - Small and open- and/or lighter-crowned } \\
\text { trees species preferable } \\
\text { - Stand density, crown size, crown density } \\
\text { and tree height to be kept to minimum by } \\
\text { regular thinning and pruning } \\
\text { - Trees should be broadly spaced apart } \\
\text { on the windward side of shallow canyons } \\
\text { (H/W } \leq 0.50)\end{array}$ \\
\hline $\begin{array}{l}\text { Low-level vegetation } \\
\text { (shrubs and hedges, with leaf cover at or } \\
\text { near the ground level) }\end{array}$ & $\begin{array}{l}\text { - Similar to many of the above } \\
\text { - Shrubs and hedges to form a contiguous } \\
\text { barrier with trees, or be trained to a height } \\
\text { of at least } 2 \mathrm{~m} \text { (above breathing height for } \\
\text { pedestrians) } \\
\text { - Barrier aligned parallel and proximate } \\
\text { to the road, where low-level vegetation } \\
\text { can mitigate pollutants at typical vehicle } \\
\text { exhaust height }\end{array}$ & $\begin{array}{l}\text { - Can be efficient for footpaths in shallow } \\
\text { street canyons } \\
\text { - A central hedgerow is better than along } \\
\text { each side of the street } \\
\text { - Continuous hedgerow through length of } \\
\text { street canyon } \\
\text { - Hedge/shrub height and porosity to } \\
\text { carefully decided based on contextual } \\
\text { factors } \\
\text { - Very low-level shrubs recommended for } \\
\text { mid-depth canyons (H/W: } 0.5-2) \\
\text { - Dense vegetation with optimal height of } \\
\text { about } 2 \text { m for shallow canyons (H/W } \leq 0.50) \\
\text { - Not recommended in deep street canyons } \\
\text { (H/W } \geq 2 \text { ) }\end{array}$ \\
\hline
\end{tabular}

- Safety issues, antisocial behavior, vandalism and fear of crime

- Gentrification and replacement of residents with low socioeconomic status
(D) Multi-stakeholder engagement: The above, however, can only materialize when envisioned with an ecosystem of stakeholders-urban planners, regulators, investors, NGOs, and residents'
Fig. 4 Classificatory scheme for urban street canyons, with respect to building geometries and wind flow directions. $\mathrm{H}=$ building height; $\mathrm{W}=$ street width; $\mathrm{L}=$ street length (authors' own illustration)

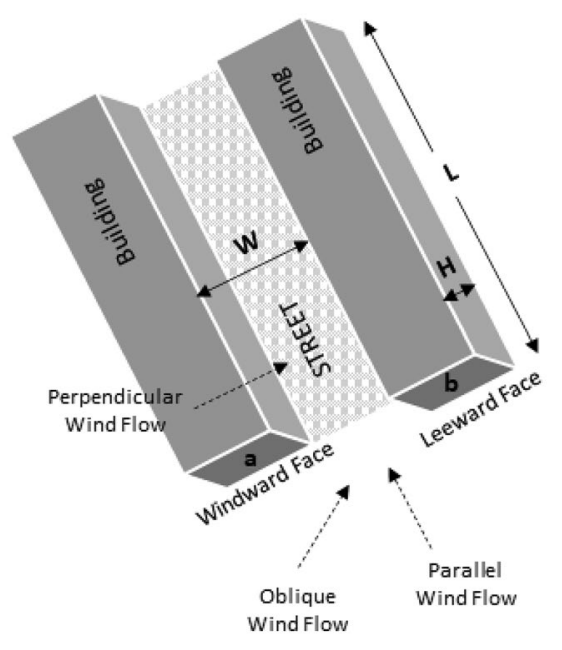

Canyon Classification

$\mathrm{H} / \mathrm{W} \leq 0.50 \quad$ Avenue Canyon

$0.50<\mathrm{H} / \mathrm{W}<2.0$ Regular Canyon

$\mathrm{H} / \mathrm{W} \geq 2.0 \quad$ Deep Canyon

$\mathrm{L} / \mathrm{W} \leq 1.0 \quad$ Short Canyon

$1.0<\mathrm{L} / \mathrm{W}<5.0 \quad$ Medium Canyon

$\mathrm{L} / \mathrm{W} \geq 5.0 \quad$ Long Canyon

$\mathrm{H}_{\mathrm{a}}=\mathrm{H}_{\mathrm{b}} \quad$ Symmetric Canyon

$\mathrm{H}_{\mathrm{a}} \neq \mathrm{H}_{\mathrm{b}} \quad$ Asymmetric Canyon

$\mathrm{H}_{\mathrm{a}}<\mathrm{H}_{\mathrm{b}} \quad$ Asymmetric Step-up Canyon

$\mathrm{H}_{\mathrm{a}}>\mathrm{H}_{\mathrm{b}} \quad$ Asymmetric Step-down Canyon 
(a)

\section{Perpendicular wind across main street axis}

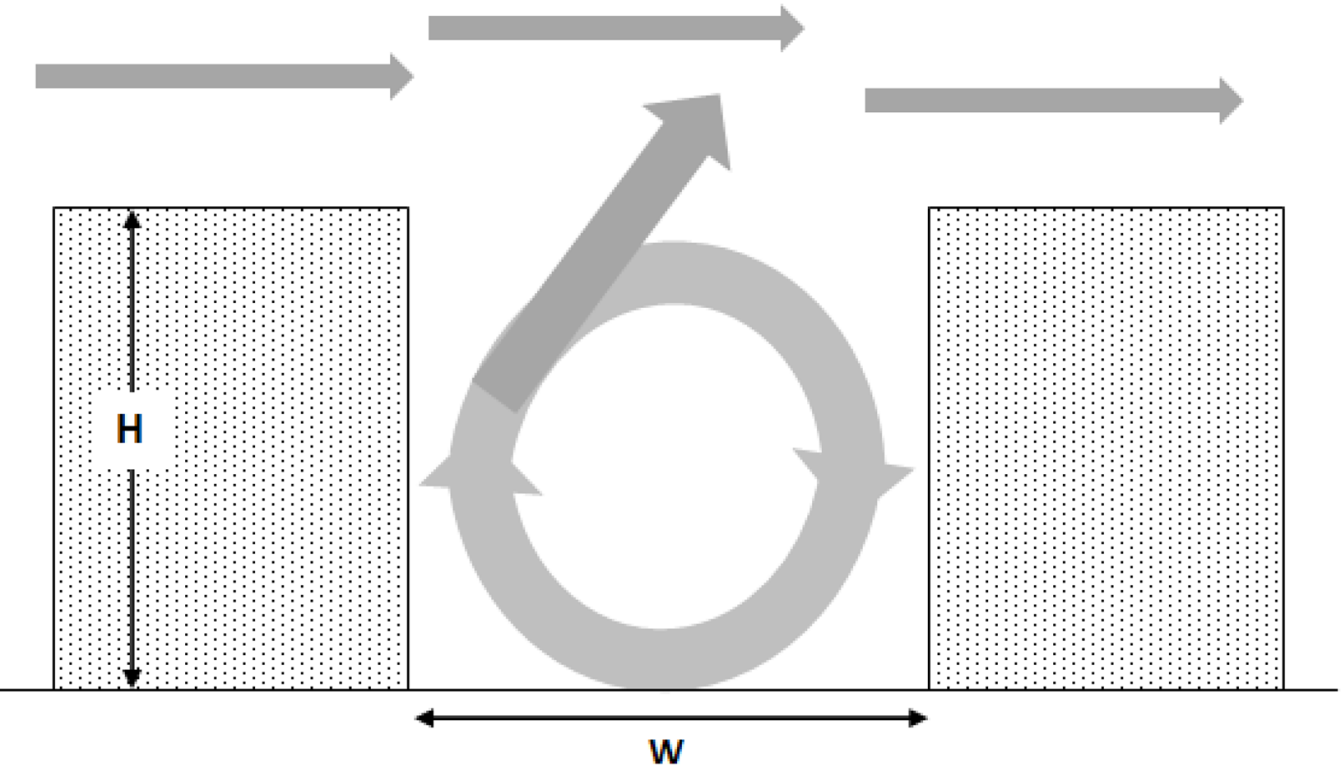

(b)

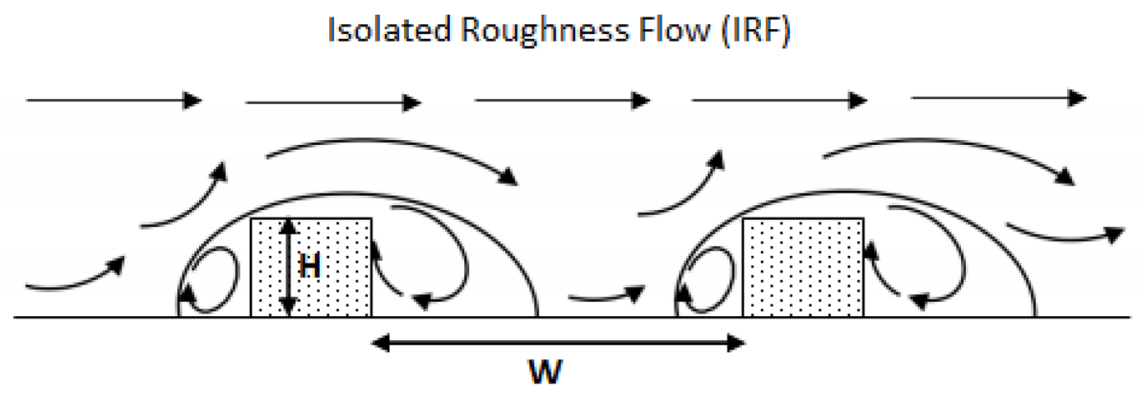

Wake Interface Flow (WIF)

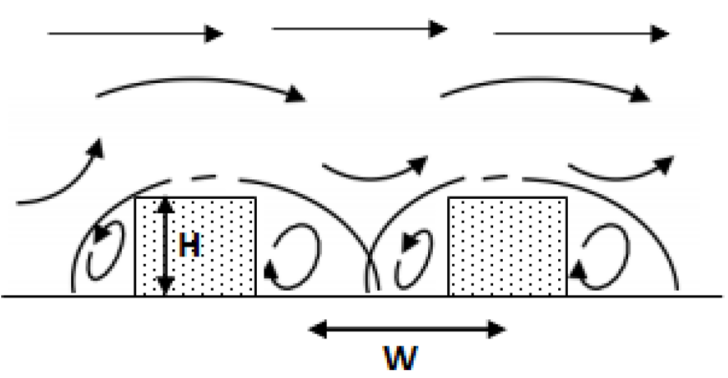

Skimming Flow (SF)

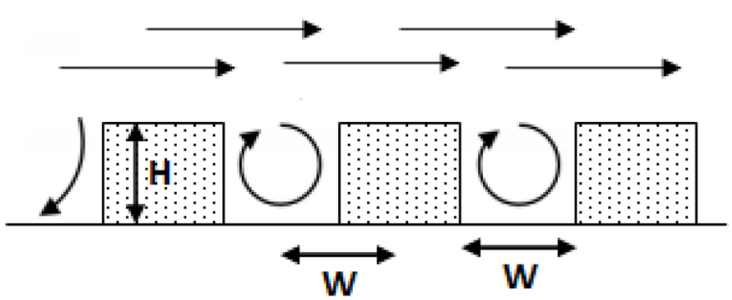

Fig. 5 a Simplified depiction of formation of primary wind vortex within urban street canyon with respect to perpendicular wind flow. b Wind flow regimes in various street canyon configurations commonly encountered in urban habitats 

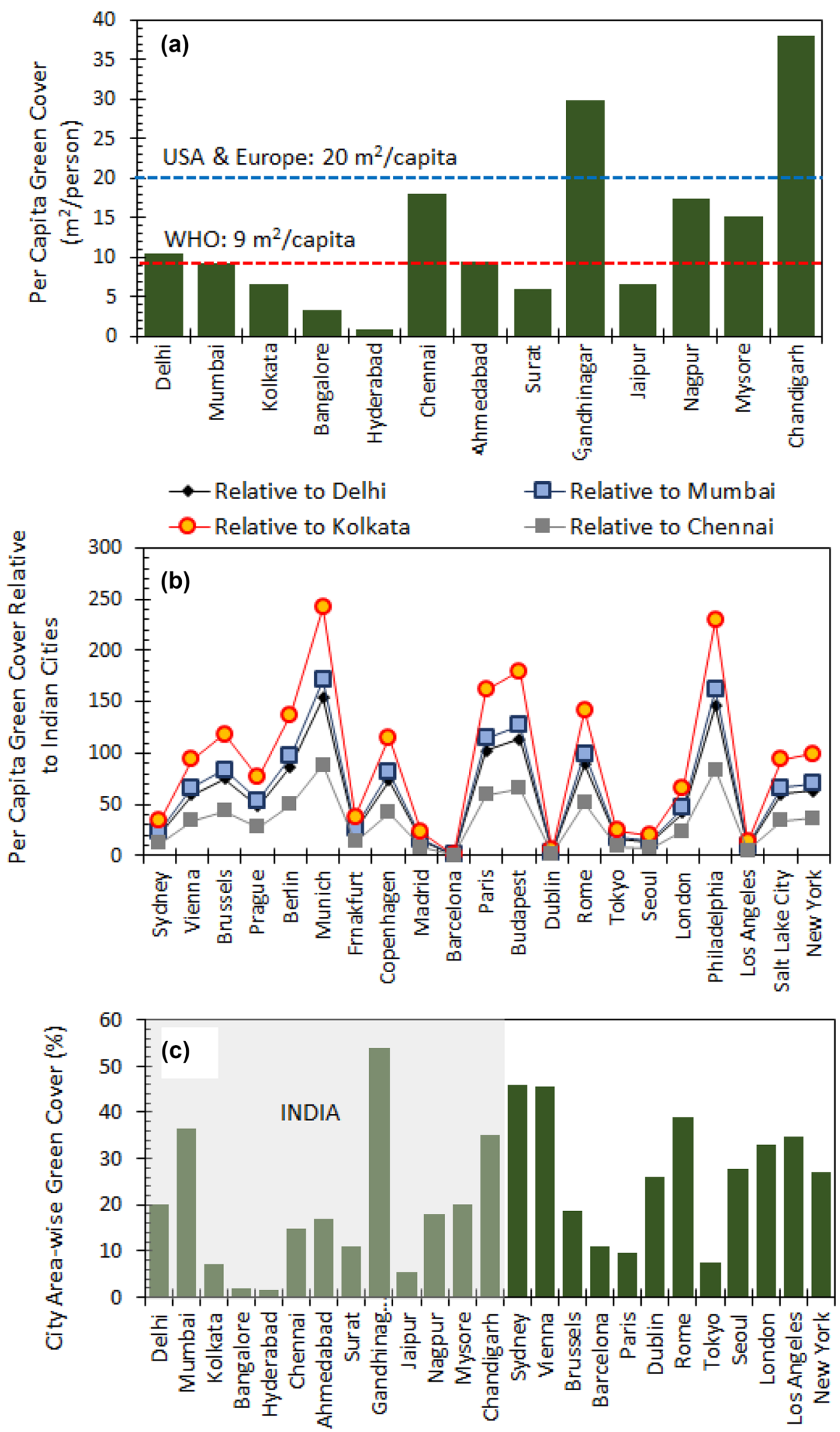
4Fig. 6 Availability of a per capita urban green cover $\left(\mathrm{m}^{2} / \mathrm{per}\right.$ son) in different Indian cities, b per capita green cover in different world cities relative to four major Indian cities, and c city-wise percentages of green cover in India and world cities (authors' own illustration; Data Source: OECD Stats; World Cities Culture Forum: http://www.worldcitiescultureforum.com/ data/of-public-green-space-parks-and-gardens)

communities-to develop mutually agreed-upon protocols of implementation. Following stakeholders might be approached:

- Public sectors, including environment, urban development, transport, health, social affairs, to maximize benefits and prevent unintended negative impacts

- Local entrepreneurs and organizations to support maintenance

- Environmental experts, academic institutes and research centers for research, innovation, monitoring, and performance evaluation.

- Local authorities, law enforcement officials.

(E) Outreach and promotion: Strategic outreach and promotion activities could be game changers ensuring optimal use of urban greenery. Interventions should take on a dual approach through which physical changes (such as creating new or improving existing green space) are accompanied by social promotion activities. The latter can include a variety of coordinated actions, depending upon the city/neighborhood contexts:

- Promotion through websites, onsite signs, brochures and similar

- Facilitated activities and public events such as family days, sports events, festivals and markets

- Small-scale group activities such as guided walks or green gyms

- Local champions and celebrities, who are very effective for promoting the use of urban green spaces and engaging the local community

- Setting up or collaborating with local organizations to (help) run and maintain the urban green spaces or to use them for their activities (such as urban gardening allotments)
Potential downsides: process-level reserch?

Deposition, re-suspension, $b$ VOC emissions

Urban authorities should be cognizant of potential flipsides of using urban greenery for pollutant removal. At fundamental level, sustained pollutant deposition on foliar surfaces can negatively alter tree physiology and functioning in multiple ways, which in turn, will reduce pollutant removal capacity. Common observations include, reduction in leaf dry weight, destruction of photosynthetic pigments, damaged cell membrane permeability, stomatal index, and develop oxidative stresses (Chaudhury \& Rathore, 2018; Clark et al., 2008; Currie \& Bass, 2008; Leghari \& Zaidi, 2013). More recent research reveals damage of optical properties, especially leaf surface reflectance in the visible and near infrared region (Gupta et al., 2016a, b); pollination and reproduction (Lewis et al., 2017; Waser et al., 2017); reduction in photosynthetic pigments including chlorophyll "a," "b," and carotenoids (Joshi \& Swami, 2009; Sen et al., 2017); enhancement of transpiration, thereby risking rapid water loss (Kameswaran et al., 2019), to name a few. We urge the urban authorities to consult the work of Muthu et al. (2021), who summarized potential adversities of pollution on roadside plants (Table 4).

Research has shown that leaf is, by far, the most vulnerable part. However, magnitude of the impact varies from species to species, due to variations in leaf orientation, phyllotaxy, cuticular and epidermal features (Chaturvedi et al., 2013b). Research reveals that in accordance with their pollution tolerance levels, internal biochemical processes of plants could be altered differently, leading to accumulation of certain metabolites (Agbaire \& Esiefarienrhe, 2009). Detection of the latter may serve as early warning of growing pollution level. For example, proline act as a free radical scavenger to protect plants from damage by oxidative stress, which particularly accumulates under environmental stress (Wang et al., 2009). Proline functions as a metal chelator and osmoprotectant (Manjunath \& Reddy, 2019). Proline maintains the intracellular redox potential that helps in stabilizing the protein 


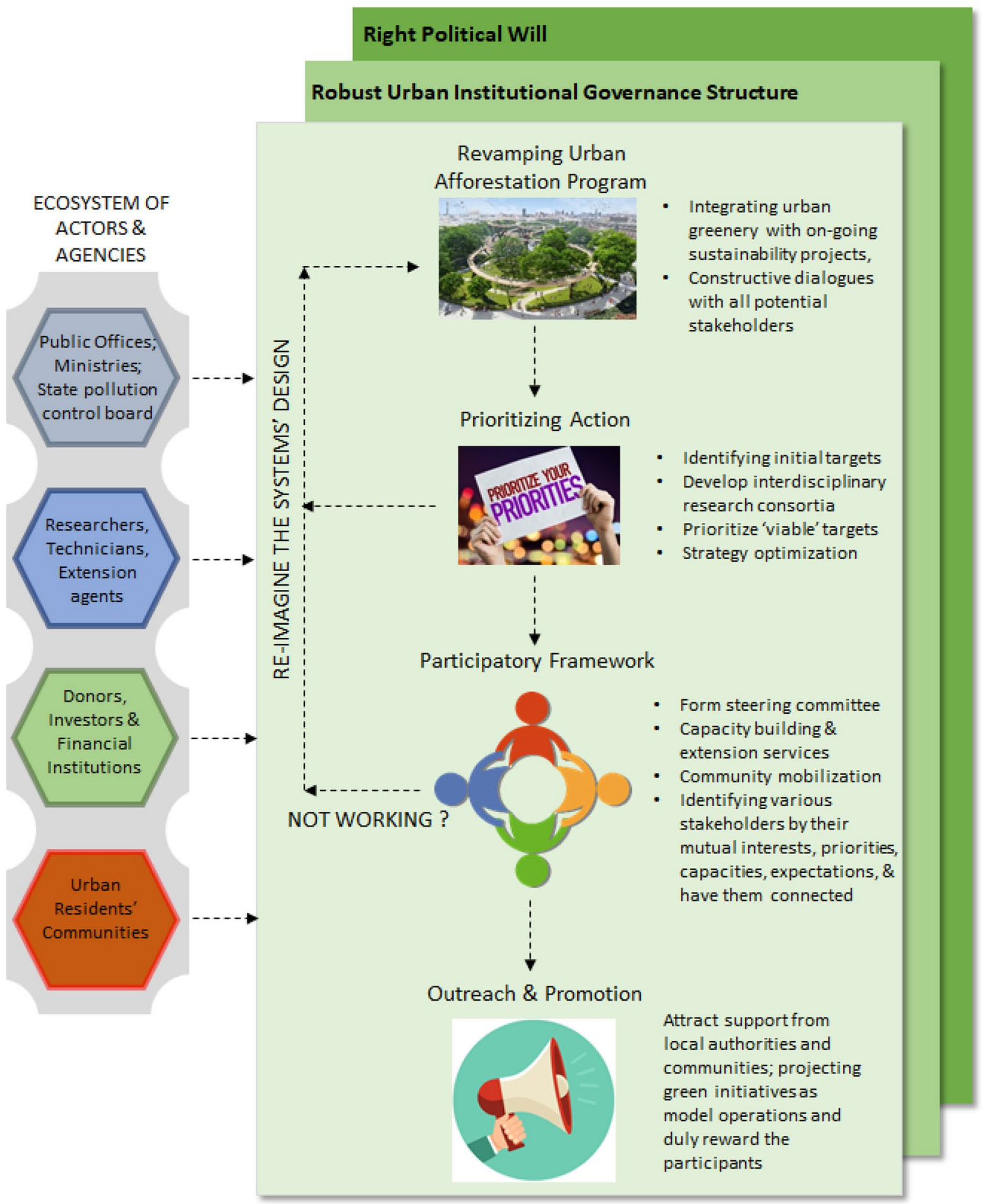

Fig. 7 A potential systems' design to implement urban greenery, strategically supported and mobilized by an ecosystem of actors and agencies. It is an iterative process, envisioned within a robust institutional structure and political system (authors' own illustration) 
Fig. 8 Prioritizing action in pollution hot spots. Greening initiatives should be realized within a multilayered systems' design, cross-linking urban environmental policy outlook, opportunities of finance, and effectiveness of existing institutions (authors' own illustration)

\section{(1) INSITUTIONAL GOVERNANCE}

\section{INVESTIMENT}

\section{POLICY APPRIASAL}

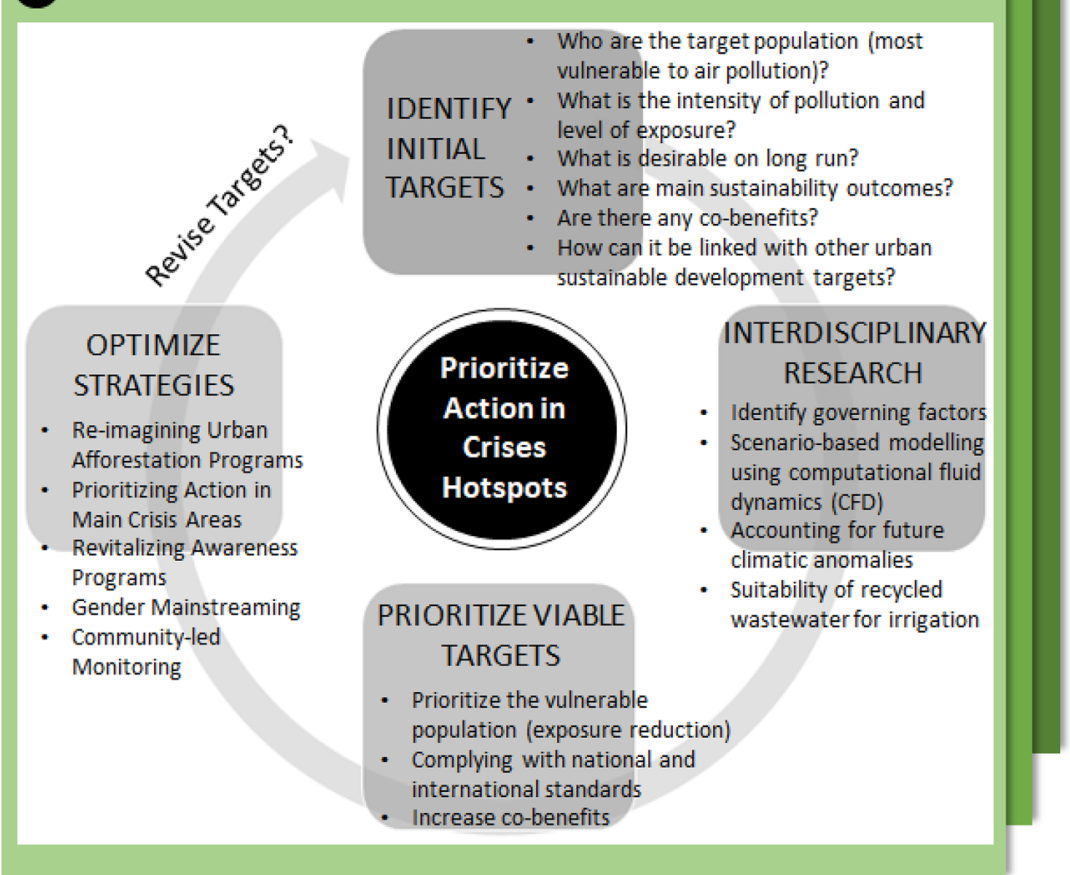

1. Community participation - Right political will

2 Public-Private Partnerships (PPP model of financing)
- Aligning with mainstream urban development targets - Ensuring mutually reinforcing policies with other sustainable development sectors conformation and membrane potential thereby enhance the tolerance potential of plants by regulating water potential which is impaired by heavy metals.Studies have shown close associations between accumulation of proline and elevated $\mathrm{SO}_{2}$ levels in ambient air (Sen et al., 2017; Seyyednejad et al., 2009), and thus an effective way to monitor ambient air pollution levels. Takahashi et al. (2020)
Table 4 Adverse impacts of air pollution on roadside plants ( source: Muthu et al., 2021)

\begin{tabular}{ll}
\hline Source type & Impact on trees \\
\hline Vehicular emission & - Reduced growth and reduction in leaf \\
& numbers \\
& Variations in leaf anatomy, morphology, \\
& reduced chlorophyll contents \\
& - Damages on flowers and seeds \\
& - Increased leaf temperature \\
& Stomatal blockage and reduction in diffusion \\
& resistance of the leaf \\
& epidermal cells \\
Vehicle-induced dust & Dust covered leaves absorbed more radiation \\
& - Damaged leaves \\
&
\end{tabular}


urged for more process-level research to understand if decline in forest stands in East Asia (Japan, Korea, China, Siberia, and the Russian Far East), is due to coupled impacts of air pollution and climate change.

Moreover, there are risks of re-suspension-a phenomenon where pollutants deposited on foliar surfaces are knocked loose by rain (or storm), thus renewing public health hazards (Chen et al., 2017; Nowak et al., 2013). It will require process-level research of leaf micro-morphology (thickness of wax layers, density and patterns of trichomes), which gives rise to "favorable" contact angles between water droplets and foliar surfaces, leading to re-suspension (Pace \& Grote, 2020). Wang et al. (2015) particularly emphasized on the role epicuticular wax ultra-structures play in particulate matter retention-the order generally decreasing as, wax films $>$ platelets $>$ tubules.

\section{Biogenic emissions}

Another downside of using urban greenery includes biogenic emissions of volatile organic carbons (bVOCs) from foliage (Abhijith et al., 2017; Hewitt et al., 2019; Nowak et al., 2013; Ram et al., 2015). Such risks are escalated by climate change (Fitzky et al., 2019). In Indian conditions, bVOCs (e.g., isoprene, aldehydes, ketones) should be of special concern to the urban authorities, due to of elevated ambient temperatures and anthropogenic emissions, which escalates bVOC emission risks (Churkina et al., 2015). Risk of bVOC emissions is low below $20^{\circ} \mathrm{C}$, and rises with temperature, until peaking between $35^{\circ} \mathrm{C}$ and $40{ }^{\circ} \mathrm{C}$ (AQEG, 2018). To that end, we particularly emphasize the need of integrating bVOC emission with climate modeling to understand risks under various climate scenarios.

\section{Bioindicators—biomonitoring?}

To that end, process-level investigation of changes in tree physiology can offer the urban authorities bioindicators of air pollution (Chaudhuri et al., 2020a, b, c; Sen et al., 2017; Thawale et al., 2011). Using ecophysiological characteristics of trees for biomonitoring of air pollution could help the urban authorities in efficient decision making in future. It is, as Gillooly et al. (2016) pointed out, "biomonitoring is a low-cost sampling method and may potentially fill an important gap in current air monitoring methods by providing low-cost, longer-term urban air pollution measures." By the same token, such tactic can improve spatially resolved exposure assessments for epidemiological studies and urban planning strategies. For example, elevated pollutant levels in ambient air often induce stomatal closure, thereby reducing $\mathrm{CO}_{2}$ availability in leaves, which in turn, affect $\mathrm{C}$-fixation pathways. Overall, such processes affect net photosynthetic rates and tree growth, which, the authorities could use early warning symptoms of growing pollution levels (Woo et al., 2007). The authors observed that elevated ambient air pollutant levels, besides suppressing photosynthetic activities, can also increase activities of the antioxidative enzymes ascorbate peroxidase and glutathione reductase. Mukherjee et al. (2019) observed that plants exposed to elevated concentrations of air pollutants have higher levels of phenols, proline, malondialdehyde, and cellulose, in Mangifera indica (mango), while reduces chlorophyll contents, which could be used as bioindicators. Tripathi and Gautam (2007) analyzed species such as Mangifera indica, Linn., Cassia fistula, Linn., and Eucalyptus hybrid, and observed that variation in chlorophyll, protein, soluble sugar free amino acid, ascorbic acid, nitrate reductase, superoxide dismutase and peroxidase in leaves were pollution load dependent, and thus, could be used as effective bioindicators of air pollution.

Potential future directions: harnessing co-benefits?

Besides, the need to advance our process-level understandings of the science of urban greenery in air pollution prevention and control, urban authorities should also be cognizant of yet another aspect: How to foster right political will and attract funding. In developing nations such as India, a great deal, if not all, the decisions are made in top-down fashion, and dictated by electoral politics, which almost always take a populist path and shoves environmental issues to the backbench (Chaudhuri \& Roy, 2017d, 2019; Chaudhuri et al., 2020b, c). By the same token, a key question is: How to convince the decision makers to bring in newer and innovative policies/regulations, while 'amending' existing ones as necessary. 
A means to envision such possibilities is probably to harness the co-benefits of urban greeneryextending its importance beyond mere air pollution mitigation. Benefits of urban greenery should be more tangible than hypothetical, and realized in day-to-day lives. To that end, we believe that the idea should be to adopt an integrative approach that strategically combines technocratic advances (e.g., clean fuel, electronic vehicles) with social dimensions (Ankita et al., 2022) and environmental sustainability with community wellbeing (Parakh \& Chaudhuri, 2022). The latter can also become a key tool to garner finance, mobilize urban communities around a common cause, and attract a wide spectrum of stakeholders, to become part of the initiative "voluntarily." Herein, we attempt to highlight certain generic observations from world literature about co-benefits of urban greenery, which should be researched in future with targeted case studies.

\section{Eco-environmental benefits}

A rich body of global literature expounds upon beneficial impacts of healthy urban vegetation/forestry in multiple spheres of urban sustainability that includes stormwater runoff control, carbon sequestration, urban shading and cooling, soil-water pollution prevention, and biodiversity conservation. Tiwary et al. (2016) had devised a combined performance evaluation framework for streetscape vegetation design, which integrates several indicators, including determination of pollution flux and thermal comfort potentials, noise reduction, carbon sequestration, etc. (Table 5). To understand the impact of biogenic emissions, and associated hazards, we particularly urge the urban authorities to pay heed to the pollution flux potential (PFP), which offers clues into likely ozone emission hazards from the proposed varieties of tree species.

The PFP of a tree species expresses the relative proportion of net annual pollutant deposition $\left(\mathrm{P}_{\mathrm{dep}}\right)$ and emission $\left(\mathrm{P}_{\text {emit }}\right)$, weighted by its seasonal leaf cover profile. The latter is a coupled function of the leaf cover during full foliation (LAI, leaf area index) and its annual profile (intra-annual foliage factor, IAL - ratio of the number of months with foliage cover to the total number of months in a year). The term $\mathrm{P}_{\mathrm{emit}}$, in the PFP equation, includes emissions of

Table 5 Useful indicators to harness co-benefits of urban greenery ( source: Tiwary et al., 2016)

\begin{tabular}{|c|c|c|}
\hline Index & Significance & Estimation method \\
\hline Pollution flux potential (PFP) & $\begin{array}{l}\text { Accounts for interactions of foliage with } \\
\text { street environment }\end{array}$ & $\begin{array}{l}\text { PFP }=\left(1-\frac{P_{\text {dep }}}{\mathrm{P}_{\text {emit }}}\right) \times \text { LAI } \times \mathrm{IAL} \\
\mathrm{P}_{\text {dep }}: \text { Annual pollutant deposition } \\
\mathrm{P}_{\text {emt }}: \text { Annual pollutant emission } \\
\text { LAI: Leaf area index } \\
\text { IAL: Intra-annual foliage factor }\end{array}$ \\
\hline Carbon sequestration potential (CSP) & $\begin{array}{l}\text { Can sequester substantial amount of } \\
\text { atmospheric carbon and thus contribute to } \\
\text { urban climate action plan }\end{array}$ & $\begin{array}{l}\mathrm{CSP}=\mathrm{AGB} \times \mathrm{C} \times \mathrm{TBCF} \\
\mathrm{AGB}: \text { Aboveground biomass } \\
\mathrm{C}: \text { Carbon content of dry biomass } \\
\text { TBCF: Total biomass conversion factor }\end{array}$ \\
\hline Thermal comfort potential (TCP) & $\begin{array}{l}\text { Regulate urban ambient air temperature } \\
\text { (urban heat island) and drought }\end{array}$ & $\begin{array}{l}\text { TCP }=\text { TCA } \times \text { LAI } \\
\text { TCA: Total canopy area } \\
\text { LAI: Leaf area index }\end{array}$ \\
\hline Noise attenuation potential (NAP) & $\begin{array}{l}\text { Effective in traffic noise attenuation closer to } \\
\text { the roads up to } 5 \mathrm{e} 10 \mathrm{~dB} \text { compared to bare } \\
\text { grass }\end{array}$ & $\begin{array}{l}\text { NAP }=\left(\frac{\mathrm{ALB}}{\mathrm{TCA}}\right) \times \mathrm{IAL} \\
\text { ALB: Average leaf biomass } \\
\text { TCA: Total canopy area } \\
\text { IAL: Intra-annual foliage factor }\end{array}$ \\
\hline Biomass energy potential (BEP) & $\begin{array}{l}\text { Woody vegetation can be an important } \\
\text { renewable resource for bioenergy }\end{array}$ & $\begin{array}{l}\mathrm{BEP}=\left(\mathrm{HHV}-\frac{\mathrm{LH} \times \mathrm{W} \times \mathrm{H}_{\mathrm{dry}}}{100}\right) \times \mathrm{AGB} \\
\text { HHV: Total heat energy in fuel } \\
\mathrm{LH}: \text { Latent heat of water vaporization } \\
\mathrm{W}: \text { Quantity of water formed by } 1 \mathrm{~g} \text { hydrogen } \\
\text { AGB: Aboveground biomass }\end{array}$ \\
\hline
\end{tabular}


isoprene, monoterpenes and other bVOCs. In addition, bVOCs are major sources of ambient ozone (Calfapietra et al., 2013), important contributors of carbon and aerosols in urban atmosphere, and facilitates acid deposition.

\section{Community wellbeing}

Besides effective air pollutant removal, recent research has shown that urban green spaces have positive impacts on human physiology and mental health (Vilcea \& Sosea, 2019). It will require strategic greening of under-utilized brownfield sites, through the implementation of parks, playgrounds, greenways, and other open spaces (van Leeuwen et al., 2010). Baycan-Levent et al. (2009) outlined a taxonomy of potential values for urban green spaces:

- Ecological: intrinsic natural value, genetic diversity value, life-support value

- Economic: market value

- Social: recreational value, aesthetic value, cultural symbolization value, historical value, characterbuilding value, therapeutic value, social interaction value, substitution value

- Planning: instrumental/structural value, synergetic and competitive value

- Multidimensional: scientific value, policy value.

Strategic planning with green spaces can help developing livable urban habitats by enriching visual aspects of life and builds identity (Cetin, 2016). It is as Cetin (2015a) maintained, "It should be possible, for a city, to achieve a healthy environment, an active green space, and an urban distribution of the size of a systematic planning of functional and aesthetic qualities, and it will be possible with the development of an urban design concept." In a study involving the Yesilyuva Nature Park, in Burdur, Truky, Cetin (2018b) emphasized that with strategic maintenance and protection, natural parks can become a marker of the region's natural and cultural heritage, and generate great deal of eco-tourism opportunities. We urge the urban authorities to consult the work of, Jansson (2014), who, in a comprehensive review of global literature, grouped the prime social/community benefits of urban green spaces under few main themes (Table 6). However, it will require full-scale feasibility assessment involving strengths, weaknesses, opportunities and threats
(SWOT), using context-specific socio-demographic and environmental traits.

\section{Mapping biocomfort zones?}

Cetin $(2015 b, 2019 b, c)$ urged the urban authorities to consider developing 'bioclimatic comfort' maps in rapidly growing urban habitats, by strategically integrating local meteorological with air quality information. It owes to the cyclic feedback loops between meteorology (temperature, relative humidity, wind flow regime) and air quality, and how they influence local weather/climate patterns. Regulatory authorities and urban sustainability planners should develop process-level understanding of how urban meteorology is governed by green spaces; how building density should be "optimized," so as to build healthy habitats. A major incentive to such action is ensuring naturebased local climate control mechanisms so as to avoid the urban heat island (UHI) scenarios, a growing concern in the twenty-first century (Cetin, 2020).

However, successful integration of nature within the urban environment requires careful deliberation on certain factors including:

- Effective application of ecological knowledge

- Integration of complementary approaches of the relevant professions

- Adequate training in ecology for those involved in open space management

- Public planning interpretation of urban nature

- Stable partnerships with the local authorities and residents' communities.

A major research and policy challenge in days ahead will be to develop an integrative framework for urban green policy in relation to its functionaleconomic uses. Planning practices for compact cities need to strategically incorporate urban green spaces that are close to people, coherent and of sufficient size, varied, well-maintained and where people can engage in development (Jansson, 2014).

These rather general and non-quantified quality guidelines may serve to provide various ecosystem services, benefits and values but will need to be adapted to site-specific prerequisites for functional densification (Berg et al., 2012). It calls for more targeted research to advance our understanding of which attributes of urban greenery can provide enhanced 
Table 6 Potential impacts of urban greenery on social and community life in urban neighborhoods

\begin{tabular}{|c|c|}
\hline Benefits & Salient observations \\
\hline Economic & $\begin{array}{l}\text { - Increased property values in the proximity of urban green spaces (Jim \& Chen, 2010) } \\
\text { - Consumer behavior is affected by the physical environment outside shops, increasing willingness-to-pay more } \\
\text { (Joye et al., 2010) } \\
\text { - Urban green spaces play a major role in city branding or place branding, whereby cities or regions brand their } \\
\text { local identity to attract companies, qualified workers and tourists (Dodds \& Joppe, 2001; Eagles, 2002; Notaro \& } \\
\text { de Salvo, 2010) }\end{array}$ \\
\hline Ecological & $\begin{array}{l}\text { - Preservation of species and biodiversity conservation (Dearborn \& Kark, 2010) } \\
\text { - Preservation/rejuvenation of pollinators, such as bee species (Potts et al., 2010) } \\
\text { - Noise reduction (Fang \& Ling, 2005), which can serve to reduce the risk of high blood pressure (Bodin et al., } \\
\text { 2009) and cardiovascular diseases caused by traffic noise (Babisch, 2008) } \\
\text { - Cooling and shading effects (Cao et al., 2010) }\end{array}$ \\
\hline Quality of life & $\begin{array}{l}\text { - People living in greener surroundings report less mental fatigue, aggressive behavior and violence and safety than } \\
\text { others (Kuo, 2003) } \\
\text { - Viewing green spaces from the office window increases work satisfaction and quality of life (Dravigne et al., } \\
\text { - } 2008 \text { ) } \\
\text { - The possibility of visiting or seeing green spaces at work reduces stress levels (Lottrup et al., 2013) } \\
\text { - } 2009 \text { ) } \\
\text { - Vegetation in urban areas is associated with lower levels of property and violence crime (Wolfe \& Mennis, 2012) } \\
\text { - Trees have positive effects on driver behavior (Dumbaugh \& Gattis, 2005). Car drivers perceive streets with trees } \\
\text { as safer and keep lower speeds there (Rosenblatt et al., 2008), while also feeling less frustrated (Cackowski \& } \\
\text { Nasar, 2003) } \\
\text { - Social benefits of urban green space include integration within and between different ethnic groups (Peters et al., } \\
\text { - } 2010 \text { ) } \\
\text { siving close to green spaces with recreational values is much favored (Björk et al., 2008), while lack of green }\end{array}$ \\
\hline
\end{tabular}

ecosystem services and benefits in sustainable compact cities. In this regard, (Cetin et al., 2019c, 2021) advocated intelligent use of a combination of satellite imagery and robust geographic information system (GIS).

\section{Conclusion}

Continued public health threat due to poor ambient air quality undermines sustainability initiatives in most urban habitats in India, in the post COVID19 lockdown periods. Urban air pollution is held accountable for mortality, from adults to children, which in future may take alarming tolls over human resources. So far, however, most initiatives have failed to deliver desired outcomes, probably because of purely technocratic vision that ignores the sociocultural dimension of pollution prevention and control. Here, we distill current research and innovation from a large number of recent global literature (post2005), to present the core tenets of urban greenery, for the urban authorities to consider complementing existing pollution control initiatives. Besides the scientific and research community, the study also targets a broad spectrum of readership, including the policymakers, practitioners, NGOs, and above all, the urban residents' community.

Besides tree species selection, which has been the prime focus of most Indian literature, we reflect on several key aspects of urban greenery that have yet largely been overlooked, including:

- Design criteria for effective urban greenery in some atypical urban configurations (street canyons and open road)

- Means to harness co-benefits, and widen opportunities of urban greenery

- Need of a systems' thinking approach, centering on participatory engagement

- Need of a robust outreach program

- Potential flipsides of urban greenery.

The latter would require process-level research with increased case studies, especially the risks of 
re-suspension of traffic-induced dust and likelihood of bVOC emissions.

Besides positive environmental outcomes, we urge urban authorities to realize that how strategically developed, and curated, green spaces might reinforce the identity of towns and cities, individuals and communities, to generate value-added living and working conditions. It was time the authorities realized, how carefully planned initiatives could attract investment and tourism, generate newer and "cleaners" livelihood opportunities, add to real estate values, and cut down on public health costs. It was time the authorities realized that these green spaces can contribute positively to both the quality of life/mind and increase the competitiveness of cities. To that end, we urge the authorities to deliberate on the works of Tiwary et al. (2016), Jansson (2014) and Cetin (2015b, 2019b, c), which should be studied in details and considered for mutually reinforcing measures, rather than standalone, to develop best use of urban green spaces.

However, the urban authorities should also bear in mind that establishing functional urban greenery is a time consuming and iterative exercise that calls for visions and revisions, an ecosystem of actors, agencies, researchers, and resident communities, cross-linked within a participatory action framework, to harness synergies between various actions (and minimize trade-off) down the value chain. We do not propose this narrative as a step-by-step, instructional manual to establish functional urban greenery, for which the authorities should seek more in-depth scientific, technical, legal, social and financial advice. However, given the current situation of ambient air quality and burgeoning public health calamities in many Indian cities, we present this narrative as an alternative vision to bolster air pollution mitigation initiatives which will be cost effective (as compared to clean fuel and emission reduction), yet long-term.

Acknowledgements We thankfully acknowledge the Center for Environment, Sustainability and Human Development, and Jindal School of Liberal Arts and Humanities (JSLH), O.P. Jindal Global University.

\section{Declarations}

Conflict of interest The authors declare no competing interests.

Disclaimer Views expressed in this study are the authors' own and do not reflect that of the affiliated organizations'.

\section{References}

Abhijith, K. V., Kumar, P., Gallagher, J., McNabola, A., Baldauf, R., Pilla, F., Broderick, B., Di Sabatinoi, S., \& Pulvirenti, B. (2017). Air pollution abatement performances of green infrastructure in open road and built-up street canyon environments-A review. Atmospheric Environment, 162, 71-86.

Abhijith, K. V., \& Gokhale, S. (2015). Passive control potentials of trees and on-street parked cars in reduction of air pollution exposure in urban street canyons. Environmental Pollution, 204, 99-108.

Ackerly, D., Knight, C., Weiss, S., Barton, K., \& Starmer, K. (2002). Leaf size, specific leaf area and microhabitat distribution of chaparral woody plants: Contrasting patterns in species level and community level analyses. Oecologia, 130, 449-457.

Agbaire, P.O. \& Esiefarienrhe. (2009). Air pollution tolerance indices (APTI) of some plants around Otorogun Gas Plant in Delta State, Nigeria. Journal of Applied Sciences and Environmental Management, 13(1). https://doi.org/ 10.4314/jasem.v13i1.55251

Ahmed, K., Khare, M., \& Chaudhry, K. K. (2008). Model vehicle movement system in wind tunnels for exhaust dispersion studies under various urban street configurations. J Wind End Ind Aerodyn., 90, 1051-1064.

Altaf, R., Altaf, S., Hussain, M., Shah, R. U., Ullah, R., Ullah, M. I., Rauf, A., Ansari, M. J., Alharbi, S. A., Alfarraj, S., \& Datta, R. (2020). Heavy metal accumulation by roadside vegetation and implications for pollution control. PLoS ONE, 16(5), e0249147. https://doi. org/10.1371/journal.pone.0249147

Anjum, N. A. (2020). Good in the Worst: COVID-19 Restrictions and Ease in Global Air Pollution. Preprints. https:// doi.org/10.20944/preprints202004.0069.v1

Ankita, Padvetnaya, V. U., \& Chaudhuri, S. (2022). What Do Farmers Don't Know? A Generic Index to Summarize Cognitive Awareness of Groundwater-sourced Irrigation and Conservation at Grassroots. Ecology, Environment and Conservation (forthcoming).

AQEG. (2018). Effects of vegetation on urban air pollution. Air Quality Expert Group. Department for Environment, Food and Rural Affairs; Scottish Government; Welsh Government; and Department of the Environment in Northern Ireland. https://uk-air.defra.gov.uk/assets/ documents/reports/cat09/1807251306_180509_Effects_ of_vegetation_on_urban_air_pollution_v12_final.pdf

Avni, A., \& Chaudhry, P. (2016). Urban vegetation and air pollution mitigation: Some issues from India. Chinese Journal of Urban and Environmental Studies, 4(1). https:// doi.org/10.1142/S2345748116500019.

Babisch, W. (2008). Road traffic noise and cardiovascular risk. Noise \& Health, 10(38), 27-33.

Baldauf, R. (2017). Roadside vegetation design characteristics that can improve local, near-road air quality. Transportation Research Part D, 52, 354-361.

Barwise, Y., \& Kumar, P. (2020). Designing vegetation barriers for urban air pollution abatement: A practical review for appropriate plant species selection. Npj Climate and 
Atmospheric Science, 3, 12. https://doi.org/10.1038/ s41612-020-0115-3.

Basu, M. (2020). Air pollution caused 16.7 lakh deaths, Rs 2.71 lakh crore loss in India in 2019 - Lancet study. The Print. Accessed: March 3, 2021. https://theprint.in/environment/ air-pollution-caused-16-7-lakh-deaths-rs-2-71-lakh-croreloss-in-india-in-2019-lancet-study/572339/.

Baycan-Levent, T., Vreeker, T., \& Nijkamp, P. (2009). A multicriteria evaluation of green spaces in European cities. European Urban and Regional Studies., 16(2), 219-239.

Bera, B., Bhattacharjee, S., Shit, P. K., Sengupta, N., \& Saha, S. (2020). Significant impacts of COVID-19 lockdown on urban air pollution in Kolkata (India) and amelioration of environmental health. Environment, Development and Sustainability. https://doi.org/10.1007/ s10668-020-00898-5

Berg, P., Granvik, M., \& Hedfors, P. (2012). Functional density: A conceptual framework in a townscape areas context. Nordic Journal of Architectural Research, 2, 29-46.

Bodin, T., Albin, M., Ardö, J., Stroh, E., Östergren, P.-O., \& Björk, J. (2009). Road traffic noise and hypertension. Results from a cross-sectional public health survey in southern Sweden. Environmental Health, 8(38). http:// www.ehjournal.net/content/8/1/38.

Björk, J., Albin, M., Grahn, P., Jacobsson, H., Ardö, J., Wadbro, J., Östergren, P. -O., \& Skärbäck, E. (2008). Recreational values of the natural environment in relation to neighbourhood satisfaction, physical activity, obesity and wellbeing. Journal of Epidemiology and Community Health, $62(4): \mathrm{e} 2$.

Brake, S. J., Barnsley, K., Lu, W., McAlinden, K. D., Eapen, M. S., \& Sohal, S. S. (2020). Smoking upregulates angiotensin-converting enzyme-2 receptor: A potential adhesionsite for novel coronavirus SARS-CoV-2 (Covid-19). Journal of Clinical Medicine, 9(3), 841. https://doi.org/10.3390/jcm9030841

Calfapietra, C., Fares, S., Manes, F., Morani, A., \& Loreto, F. (2013). Role of biogenic volatile organic compounds (BVOC) emitted by urban trees on ozone concentration in cities: A review. Environmental Pollution, 183, 71-80.

Cao, X., Onishi, A., Chen, J., \& Imura, H. (2010). Quantifying the cool island intensity of urban parks using ASTER and IKONOS data. Landscape and Urban Planning, 96(4), 224-231.

Cackowski, J. M., \& Nasar, J. L. (2003). The restorative effects of roadside vegetation: Implications for automobile driver anger and frustration. Environment and Behavior, 35(6), 736-751.

Carpentieri, M., Kumar, P., \& Robins, A. (2011). An overview of experimental results and dispersion modelling of nanoparticles in the wake of moving vehicles. Environmental Pollution, 159, 685-693.

Cetin, M., Aksoy, T., Cabuk, S. N., Kurkcuoglu, M. A. S., \& Cabuk, A. (2021). Employing remote sensing technique to monitor the influence of newly established universities in creating an urban development process on the respective cities. Land Use Policy, 109, 105705.

Cetin, M. (2020). Climate comfort depending on different altitudes and land use in the urban areas in Kahramanmaras City. Air Quality, Atmosphere \& Health., 13, 991-999.
Cetin, M., Onac, A. K., Sevik, H., \& Sen, B. (2019a). Temporal and regional change of some air pollution parameters in Bursa. Air Quality, Atmosphere and Health, 12, 311316. https://doi.org/10.1007/s11869-018-00657-6.

Cetin, M. (2019b). The effect of urban planning on urban formations determining bioclimatic comfort area's effect using satellitia imagines on air quality: a case study of Bursa city. Air Quality Atmosphere \& Health 12(7). https://doi.org/10.1007/s11869-019-00742-4.

Cetin, M., Adiguzel, F., Gungor, S., Kaya, E., \& Sancar, M. C. (2019c). Evaluation of thermal climatic region areas in terms of building density in urban management and planning for Burdur. Turkey. Air Quality, Atmosphere and Health, 12, 1103-1112.

Cetin, M., Sevik, H., \& Yigit, N. (2018a). Climate type-related changes in the leaf micromorphological characters of certain landscape plants. Environmental Monitoring and Assessment, 190(7), 1-9.

Cetin, M., Zeren, I., Sevik, H., Cakir, C., \& Akpinar, H. (2018b). A study on the determination of the natural park's sustainable tourism potential. Environmental Monitoring and Assessment, 190(3), 1-8.

Cetin, M. (2016). Sustainability of urban coastal area management: A case study on Cide. Journal of Sustainable Forestry, 35(7), 527-541.

Cetin, M. (2015a). Using GIS analysis to assess urban green space in terms of accessibility: Case study in Kutahya. International Journal of Sustainable Development \& World Ecology, 22(5), 420-424.

Cetin, M. (2015b). Determining the bioclimatic comfort in Kastamonu City. Environmental Monitoring and Assessment, 187(10), 1-10.

Chaturvedi, R., Prasad, S., Rana, S., Obaidullah, S., Pandey, V., \& Singh, H. (2013a). Effect of dust load on the leaf attributes of the tree species growing along the roadside. Environmental Monitoring and Assessment, 185, 383-391.

Chaturvedi, A., Kamble, R., Patil, N. G., \& Chaturvedi, A. (2013b). City-forest relationship in Nagpur: One of the greenest cities of India. Urban Forestry \& Urban Greening, 12(1), 79-87.

Chaudhuri, S., Roy, M., McDonald, L. M., \& Emendack, Y. (2021a). Coping behaviours: A review of perceived social and health outcomes of food insecurity on women and children. Food Security, 13, 1049-1068.

Chaudhuri, S., Parakh, D., Roy, M., \& Kaur, H. (2021b). Groundwater-sourced irrigation and agro-power subsidies: Boon or bane for small/marginal farmers in India? Groundwater for Sustainable Development. 15(100690). https://doi.org/10.1016/j.gsd.2021.100690

Chaudhuri, S., Roy, M., McDonald, L. M., \& Emendack, Y. (2020a). Reflections on farmers' social networks: A means for sustainable agricultural development? Environment, Development and Sustainability, 23, 2973-3008.

Chaudhuri, S., Roy, M., McDonald, L. M., \& Emendack, Y. (2020b). Water for all (Har Ghar Jal): Rural water supply services (RWSS) in India (2013-20180, Challenges and Opportunities. International Journal of Rural Management, 16(2), 254-284. 
Chaudhuri, S., Roy, M., \& Jain, A. (2020c). Appraisal of WaSH (Water-Sanitation-Hygiene) Infrastructure using a Composite Index, Spatial Algorithms and Sociodemographic Correlates in Rural India. Journal of Environmental Informatics, 35(1), 1-22.

Chaudhuri, S., \& Roy, M. (2019). Irrigation water pricing in India as means to conserve water Resources: Challenges and potential future opportunities. Environmental Conservation, 46(1), 99-102.

Chaudhuri, S. (2018). Beyond temporary breathers. Millennium Post. 26 March, 2018. http://www.millenniumpost. in/opinion/beyond-temporary-breathers-291292

Chaudhuri, S., \& Roy, M. (2017a). The fight against pollution: Can Delhi better Beijing? Hindustan Times. November 15, 2017. https://www.hindustantimes.com/analysis/ the-fight-against-pollution-can-delhi-better-beijing/storyIEiGLSK5NBJOorSnJRzNZK.html

Chaudhuri, S., \& Roy, M. (2017b). Up in Smoke. The Telegraph. November 16, 2017. https://www.telegraphindia. com/opinion/up-in-smoke/cid/1455657

Chaudhuri, S., \& Roy, M. (2017c). Air pollution: Without alternatives, penalties against stubble burning will never work. The Economic Times. November 9, 2017. https:// economictimes.indiatimes.com/blogs/et-commentary/ air-pollution-without-alternatives-penalties-againststubble-burning-will-never-work/

Chaudhuri, S., \& Roy, M. (2017d). Drinking water sources in India: How safe is Safe? Current Science., 113(3), 393-402.

Chaudhury, I. J., \& Rathore, D. (2018). Suspended particulate matter deposition and its impact on urban trees. Atmospheric Pollution Research, 9(6), 1072-1082.

Chen, L., Liu, C., Zhang, L., \& Zhang, Z. (2017). Variation in Tree Species Ability to Capture and Retain Airborne Fine Particulate Matter $\left(\mathrm{PM}_{2.5}\right)$. Scientific Report. I 7(3206). https://doi.org/10.1038/s41598-017-03360-1

Clark, C., Adriaens, P., \& Talbot, F. B. (2008). Green roof valuation: A probabilistic economic analysis of environmental benefits. Environmental Science and Technology, 42(6), 2155-2161.

Churkina, G., Grote, R., Butler, T. M., \& Lawrence, M. (2015). Natural selection? Picking the right trees for urban greening. Environmental Science \& Policy, 47, 12-17.

Currie, B. A., \& Bass, B. (2008). Estimates of air pollution mitigation with green plants and green roofs using UFORE Model. Urban Ecosystem, 11(4), 409-422.

Dearborn, D. C., \& Kark, S. (2010). Motivations for conserving urban biodiversity. Conservation Biology, 24(2), 432-440.

Diener, A., \& Mudu, P. (2021). How can vegetation protect us from air pollution? A critical review on green spaces' mitigation abilities for air-borne particles from a public health perspective - with implications for urban planning. Science on the Total Environment ,796(148605). https:// doi.org/10.1016/j.scitotenv.2021.148605

Dodds, R., \& Joppe, M. (2001). Promoting urban green tourism: The development of the other map of Toronto. Journal of Vacation Marketing, 7(3), 261-267.

Dravigne, A., Waliczek, T. M., Lineberger, R. D., \& Zajicek, J. M. (2008). The effect of live plants and window views of green spaces on employee perceptions of job satisfaction. HortiScience, 43(1), 183-187.

Dumbaugh, E., \& Gattis, J. L. (2005). Safe streets, livable streets. Journal of the American Planning Association, 71(3), 283-300.

Dwivedi, A. K., \& Tripathi, B. D. (2007). Pollution tolerance and distribution pattern of plants in surrounding area of coal-fired industries. Journal of Environmental Biology, 28(2), 257-263.

Eagles, P. F. J. (2002). Trends in park tourism: Economics, finance and management. Journal of Sustainable Tourism, 10(2), 132-153.

Fang, C.-F., \& Ling, D.-L. (2005). Guidance for noise reduction provided by tree belts. Landscape and Urban Planning, 71(1), 29-34

Faruqui, N., Raman, V. R., Shiv, J., Chaturvedi, S., Mazumder, M., \& Prasad, V. (2021). Informal collectives and access to healthcare during India's COVID-19 second wave crisis. BMJ Global Health, 6, e006731. https://doi.org/10. 1136/bmjgh-2021-006731

Fitzky, A. C., Sanden, H., Karl, H., Fares, S., Calfapeitra, C., Grote, R., et al. (2019). The interplay between ozone and urban vegetation - bVOC emissions, ozone deposition, and tree ecophysiology. Frontiers in Forest and Global Change, 2, 1-17.

Frontera, A., Martin, C., Vlachos, K., \& Sgubin, G. (2020). Regional air pollution persistence links to COVID-19 infection zoning. The Journal of Infection, 81(2), 318356. https://doi.org/10.1016/j.jinf.2020.03.045

Gao, T., Liu, F., Wang, Y., Mu, S., \& Qiu, L. (2020). Reduction of Atmospheric Suspended Particulate Matter Concentration and Influencing Factors of Green Space in Urban Forest Park. Sustainability, 11(950). https://doi.org/10. 3390/f11090950

Gettleman, J., Yasir, S., \& Kumar, H. (2021). As Covid-19 Devastates India, deaths go Undercounted. New York Times 24 April 2021,. Available: https://www.nytimes. com/2021/04/24/world/asia/india-coronavirus-deaths. html [Accessed 12 Jun 2021]

Giardina, M., Donateo, A., Buffa, P., Contini, D., Cervone, A., Lombardo, C., \& Rocchi, F. (2019). Atmospheric dry deposition processes of particles on urban and suburban surfaces: Modelling and validation works. Atmospheric Environment, 214, 116857. https://doi.org/10.1016/J. ATMOSENV.2019.116857

Giardina, M., Buffa, P., Cervone, A., \& Lombardo, C. (2019). Dry deposition of particle on urban areas. Journal of Physics Conference Series, 1224. https://doi.org/10.1088/ 1742-6596/1224/1/012050

Gillooly, S. E., Shmool, J. L. C., Michanowicz Bain, D. J., Cambal, L. K., Shields, K. N., \& Clougherty, J. E. (2016). Framework for using deciduous tree leaves as biomonitors for intraurban particulate air pollution in exposure assessment. Environmental Monitoring and Assessment, 188(8), 479. https://doi.org/10.1007/ s10661-016-5482-1

Gromke, C., \& Blocken, B. (2015). Influence of avenue-trees on air quality at the urban neighborhood scale. Part II: Traffic pollutant concentrations at pedestrian level. Environmental Pollution, 196, 176-184. 
Gromke, C., \& Ruck, B. (2012). Pollutant concentrations in street canyons of different directions. Boundary-Layer Meteorol, 144, 41-64.

Gupta, G. P., Kumar, B., \& Kulshrestha, U. C. (2016a). Impact and pollution indices of urban dust on selected plant species for green belt development: Mitigation of the air pollution in NCR Delhi, India. Arab Journal of Geosciences, 9, 136. https://doi.org/10.1007/s12517-015-2226-4

Gupta, G. P., Kumar, B., Singh, S., \& Kulshrestha, U. C. (2016b). Deposition and Impact of Urban Atmospheric Dust on Two Medicinal Plants during Different Seasons in NCR Delhi. Aerosol and Air Qualilty Research, 16, 2920-2932.

Hewitt, C. N., Ashworth, K., \& MacKenzie, A. R. (2019). Using green infrastructure to improve urban air quality. Ambio, 49(1). https://doi.org/10.1007/ s13280-019-01164-3

Hirabayashi, S., \& Nowak, D. J. (2016). Comprehensive National Database of Tree Effects on Air Quality and Human Health in the United States Environmental Pollution., 215, 48-57.

Hofmann, J., \& Samson, R. (2014). Biomagnetic monitoring as a validation tool for local air quality models: A case study for an urban street canyon. Environment International, 70, $50-61$.

IQAir. (2020). World Air Quality Report: Region \& City $\mathrm{PM}_{2.5}$ Ranking. https://www.iqair.com/us/world-air-quality

Irshad, M. A., Nawaz, R., Ahmad, S., Arshad, M., Rizwan, M., Ahmed, N., et al. (2020). Evaluation of Anticipated Performance Index of Tree Species for Air Pollution Mitigation in Islamabad. Pakistan. Environmental Science and Management, 23-1, 50-59.

Janhall, S. (2015). Review on urban vegetation and particle air pollution: Deposition and dispersion. Atmospheric Environment, 105, 130-137.

Jansson, M. (2014). Green space in compact cities: The benefits and values of urban ecosystem services in planning. Nordic Journal of Architectural Research, 2, 139-160.

Jim, C. Y., \& Chen, W. Y. (2010). External effects of neighbourhood parks and landscape elements on high-rise residential value. Land Use Policy, 27(2), 662-670.

Joshi, P., \& Swami, A. (2009). Air pollution induced changes in the photosynthetic pigments of selected plant species. Journal of Environmental Biology, 30, 295-298.

Joye, Y., Willems, K., Brengman, M., \& Wolf, K. (2010). The effects of urban retail greenery on consumer experience: Reviewing the evidence from a restorative perspective. Urban Forestry \& Urban Greening, 9(1), 57-64.

Kameswaran, S., Gunavathi, Y., \& Krishna, P. G. (2019). Dust pollution and its influence on vegetation-a critical analysis. Research Journal of Life Sciences, Bioinformatics, Pharmaceutical and Chemical Sciences, 5, 341-363.

Kaur, M., \& Nagpal, A. K. (2017). Evaluation of air pollution tolerance index and anticipated performance index of plants and their application in development of green space along the urban areas. Environmental Science and Pollution Research International, 24(23), 18881-18895.

Kuddus, M., Kumari, R., \& Ramteke, P. W. (2011). Studies on air pollution tolerance of selected plant species in Allahabad city, India. Journal of Environmental Research and Management, 2(3), 42-46.
Kumar, A., \& Chaudhuri, S. (2022). Post SARS-CoV-2 urban India: Computing air quality health indicators (AQHI) for Gurugram city to assess imminent threats to public health. Ecology, Environment and Conservation, 28, S185-S193.

Kumar, A., \& Chaudhuri, S. (2021). Is COVID-19 only but a short-term respite? A case study of urban air quality in Kolkata (Calcutta), a mega-city in India. Pollution Research, 40, S163-S173.

Kuo, F. E. (2003). The role of arboriculture in a healthy social ecology. Journal of Arboriculture, 29(3), 148-155.

Larsen, K., Gilliland, J., Hess, P., Yucker, P., Irwin, J., \& He, M. (2009). The influence of the physical environment and sociodemographic characteristics on children's mode of travel to and from school. American Journal of Public Health, 99(3), 520-526.

Leghari, S. K., \& Zaidi, M. (2013). Effect of air pollution on the leaf morphology of common plant species of Quetta city. Pakistan Journal of Botany, 45, 447-454.

Lewis, M., Schupp, E., \& Monaco, T. (2017). Road dust correlated with decreased reproduction of the endangered Utah shrub Hesperidanthus suffrutescens. Western North American Naturalist, 77, 430-439.

Li, Z., Zhang, H., Wen, C.-Y., Yang, A.-S., \& Juan, Y.-H. (2020b). Effects of height-asymmetric street canyon configurations on outdoor air temperature and air quality. Building and Environment, 183, 107195. https://doi.org/ 10.1016/j.buildenv.2020.107195

Liberati, A., Altman, D. G., Tetzlaff, J., Mulrow, C., Gøtzsche, P. C., Ioannidis, J. P., Clarke, M., Devereaux, P. J., Kleijnen, J., \& Moher, D. (2009). The PRISMA statement for reporting systematic reviews and meta-analyses of studies that evaluate health care interventions: Explanation and elaboration. PLoS Medicine, 6(7), e1000100. https://doi.org/10. 1136/bmj.b2700

Liu, M., Zhu, Z., \& Sun, L. (2021). Risk factors of invasive fungal infection in recipients after liver transplantation: A systematic review and meta-analysis. Frontiers in Medicine (lausanne), 8, 687028. https://doi.org/10.3389/ fmed.2021.687028.

Lo, A. Y., \& Jim, C. Y. (2010). Willingness of residents to pay and motives for conservation of urban green spaces in the compact city of Hong Kong. Urban Forestry and Urban Greening., 9(2), 113-120.

Lodovici, M., \& Bigagli, E. (2011). Oxidative stress and air pollution exposure. Journal of Toxicology, 487074. https://doi.org/10.1155/2011/487074

Lottrup, L., Grahn, P., \& Stigsdotter, U. K. (2013). Workplace greenery and perceived levels of stress: Benefits of access to a green outdoor environment at the workplace. Landscape and Urban Planning., 110, 5-11.

Mahato, S., Pal, S., \& Ghosh, K. G. (2020). Effect of lockdown amid COVID-19 pandemic on air quality of the megacity Delhi, India. Science of the Total Environment, 730, 139086.

Mandal, P., \& Pal, S. (2020). COVID-19 pandemic persuaded lockdown effects on environment over stone quarrying and crushing area. Science of the Total Environment, 732, 139281. https://doi.org/10.1016/j.scitotenv.2020.139281

Manjunath, B. T., \& Reddy, J. (2019). Effect of air pollutants on some heavy metals and biochemical constituents of 
leaves of some plants at Bangalore city: A case study. Journal of Applied and Natural Science, 11(1), 66-75.

Moher, D., Libetary, A., Tetzlaff, J., \& Altman, D. G. (2009). Preferred reporting items for systematic reviews and meta-analyses: The PRISMA statement. BMJ, 339, b2535. https://doi.org/10.1136/bmj.b2535

Montana, M., Montero, V., Khoumeri, O., \& Vanelle, P. (2021). Quinoxaline Moiety: A Potential Scaffold against Mycobacterium tuberculosis. Molecules, 26(16), 4742. https:// doi.org/10.3390/molecules26164742

Mori, J., Fini, A., Galimberti, M., Ginepro, M., Burchi, G., Massa, D., \& Ferrini, F. (2018). Air pollution deposition on a roadside vegetation barrier in a Mediterranean environment: Combined effect of evergreen shrub species and planting density. Science of the Total Environment, $643,725-737$.

Mukherjee, A. \& Agrawal, M. (2018). Use of GLM approach to assess the responses of tropical trees to urban air pollution in relation to leaf functional traits and tree characteristics. Ecotoxicology and Environmental Safety, 152, 42-54.

Mukherjee, S., Chakraborty, A., Mondal, S., Saha, S., Haque, A., \& Paul, S. (2019). Assessment of common plant parameters as biomarkers of air pollution. Environmental Monitoring and Assessment, 191(6), 400. https://doi.org/ 10.1007/s10661-019-7540-y

Mullaney, J., Lucke, T., \& Trueman, S. J. (2015). A review of benefits and challenges in growing street trees in paved urban environments. Landscape and Urban Planning. https://doi.org/10.1016/j.landurbplan.2014.10.013.

Murena, F., \& Mele, B. (2016). Effect of balconies on air quality in deep street cayons. Atmospheric Pollution Research, 7(6), 1004-1012.

Muthu, M., Gopal, J., Kim, D. H., \& Sivanesan, I. (2021). Reviewing the Impact of Vehicular Pollution on Road-Side Plants-Future Perspectives. Sustainability, 13(5114). https://doi.org/10.3390/su13095114

Ng, W.-Y., \& Chau, C.-K. (2012). Evaluating the role of vegetation on the ventilation performance in isolated deep street canyons. International Journal of Environment and Pollution, 50, 98-110.

Nicola, F. D., Graña, E. C., Mahía, P. L., Lorenzo, S. M., Rodríguez, D. P., Retuerto, R., Carballeira, A., Aboal, J. R., \& Fernandez, J. A.(2017). Evergreen or deciduous trees for capturing PAHs from ambient air? A Case Study. Environmental Pollution, 221, 276-284.

Notaro, S., \& de Salvo, M. (2010). Estimating the economic benefits of the landscape function of ornamental trees in a sub-Mediterranean area. Urban Forestry \& Urban Greening, 9(2), 71-81.

Nowak, D. J., Hirabayashi, S., Bodine, A., \& Hoehna, R. (2013). Modeled PM2.5 removal by trees in ten US cities and associated health effects. Environmental Pollution, $178,395-402$.

Oke, T. R. (1988). Street design and urban canopy layer climate. Energy and Building, 11, 103-113.

Ortakavak, Z., Cabuk, S. N., Cetin, M., Kurkcuoglu, M. A. S., \& Cabuk, A. (2020). Determination of the nighttime light imagery for urban city population using DMSPOLS methods in Istanbul. Environmental Monitoring and Assessment, 192(12), 1-17.
Ozel, H. B., Aisha, A. E. S. A., Cetin, M., Sevik, H., \& Cetin, I. Z. (2021). The effects of increased exposure time to UV-B radiation on germination and seedling development of Anatolian black pine seeds. Environmental Monitoring and Assessment, 193(7), 1-11.

Pace, R., \& Grote, R. (2020). Deposition and resuspension mechanisms into and from tree canopies: A study modeling particle removal of conifers and broadleaves in different cities. Frontiers in Forests and Global Change, 3. https://doi.org/10.3389/ffgc.2020.00026

Panda, L. R. L., Aggarwal, R. K., \& Bhardwag, D. R. (2018). A review of Air Pollution Tolerance Index (APTI) and Anticipated Performance Index (API). Current World Environment, 13(1), 55-65.

Parakh, D., \& Chaudhuri, S. (2022). Groundwater regulation bills in Haryana-A call for groundwater conservation and management for sustainable irrigation supply servicesOpportunities and challenges. Ecology, Environment and Conservation (forthcoming).

Patel, D., \& Nirmal Kumar, J. I. (2018). An evaluation of air pollution tolerance index and anticipated performance index of some tree species considered for green belt development: A case study of Nandesari Industrial Area, Vadodara, Gujarat, India. Open Journal of Air Pollution, 7, 1-13.

Peters, K., Elands, B., \& Buijs, A. (2010). Social interaction in urban parks: Stimulating social cohesion? Urban Forestry \& Urban Greening, 9(2), 93-100.

Popek, R., Gawrońska, H., Sæbø, A., Wrochna, M., \& Gawroński, S. W. (2013). Particulate matter on foliage of 13 woody species: Deposition on surfaces and phytostabilisation in waxes - a 3 year study. International Journal of Phytoremediation, 15(3), 245-256.

Potts, S.G., Biesmeijer, J.C., Kremen, C., Neumann, P., Schweiger, O., \& Kunin, W.E. (2010). Global pollinator declines: trends, impacts and drivers. 25(6), 345-353.

Prosperini, L., Tortorella, C., Haggiag, S., Ruggieri, S., Galgani, S., \& Gasperini, C. (2021). Increased risk of death from COVID-19 in multiple sclerosis: A pooled analysis of observational studies. Journal of Neurology, 1-7. https:// doi.org/10.1007/s00415-021-10803-3

Przybysz, A., Nersisyan, G., \& Gawroński, S. W. (2019). Removal of particulate matter and trace elements from ambient air by urban greenery in the winter season. Environmental Science and Pollution Research, 26, 473-482.

Qiu, Y., Guan, D., Song, W., \& Huang, K. (2009). Capture of heavy metals and sulfur by foliar dust in urban Huizhou, Guangdong Province, China. Chemosphere, 75, 447-452.

Rahul, J., \& Jain, M. K. (2016). Effect of heavy metals on some selected roadside plants and its morphological study. Nature Environment and Pollution Technology, 15(4), 1133-1142.

Rai, P. K. (2016). Impacts of particulate matter pollution on plants: Implications for environmental biomonitoring. Ecotoxicology and Environmental Safety, 129, 120-136.

Rai, P. K., Panda, L. L. S., Chutia, B. M., \& Singh, M. M. (2013). Comparative assessment of air pollution tolerance index (APTI) in the industrial (Rourkela) and non-industrial area (Aizawl) of India: An ecomanagement approach. African 
Journal of Environmental Science and Technology, 7(10), 944-948.

Ram, S. S., Majumder, S., Chaudhuri, P., Chanda, S., Santra, S. C., Chakrabarty, A., \& Sudarshan, M. (2015). A Review on Air Pollution Monitoring and Management Using Plants with Special Reference to Foliar Dust Adsorption and Physiological Stress Responses. Critical Reviews in Environmental Science and Technology, 45(23), 2489-2522.

Ravishankara, A. R., David, L. M., Pierce, J. R., \& Venkatraman, C. (2020). Outdoor air pollution in India is not only an urban problem. Proceedings of National Academy of Sciences, 117(46), 28640-28644.

Roman, L. A., Battles, J. J., \& McBride, J. R. (2014). Determinants of establishment survival for residential trees in Sacramento County, CA. Landscape and Urban Planning, 129, 22-31.

Rosenblatt, N. J., Kweon, B. S., \& Maghelal, P. (2008). The street tree effect and driver safety. ITE Journal on the Web, 69-73.

Roupsard, P., Amielh, M., Maro, D., Coppalle, A., \& Branger, H. (2013). Measurement in a wind tunnel of dry deposition velocities of submicron aerosol with associated turbulence onto rough and smooth urban surfaces. Journal of Aerosol Science, 55, 12-24.

Rowinski, A., \& von Schreeb, J. (2021). Decontamination of Surgical Instruments for Safe Wound Care Surgeries in Disasters: What are the Options? A Scoping Review. Prehospital and Disaster Medicine, 36(5), 645-650. https://doi.org/10.1017/S1049023X2100090X.

Schaubroeck, T., Deckmyn, G., Neirynck, J., Staelens, J., Adriaenssens, S., Dewulf, J., et al. (2014). Multilayered modeling of particulate matter removal by a growing forest over time, from plant surface deposition to washoff via rainfall. Environmental Science and Technology, 48, 10785-10794.

Selmi, W., Weber, C., Riviere, E., Blond, L., Mehdi, L., \& Nowak, D. (2016). Air pollution removal by trees in public green spaces in Strasbourg city, France. Urban Forestry and Urban Greening, 17, 192-201.

Sen, A., Khan, I., Kundu, I., Das, K., \& Datta, J. K. (2017). Ecophysiological evaluation of tree species for biomonitoring of air quality and identification of air pollution-tolerant species. Environmental Monitoring and Assessment, 189(6), 262. https://doi.org/10.1007/ s10661-017-5955-x

Sert, E. B., Cetin, M., \& Turkmen, M. (2019). Heavy metal accumulation in rosemary leaves and stems exposed to traffic-related pollution near Adana-İskenderun Highway (Hatay, Turkey). Environmental Monitoring and Assessment, 191(9), 1-12.

Sevik, H., Cetin, M., Ozel, H. B., Ozel, S., \& Cetin, I. Z. (2020). Changes in heavy metal accumulation in some edible landscape plants depending on traffic density. Environmental Monitoring and Assessment, 192(2), 1-9.

Sevik, H., Cetin, M., Ozel, H. B., Akarsu, H., \& Cetin, I. Z. (2019). Analyzing of usability of tree-rings as biomonitors for monitoring heavy metal accumulation in the atmosphere in urban area: a case study of cedar tree (Cedrus sp.). Environmental Monitoring and Assessment, 192(1), 1-11.
Seyyednejad, S. M., Niknejad, M., \& Yusefi, M. (2009). The effect of air pollution on some morphological and biochemical factors of Callistemon citrinus in petrochemical zone in South of Iran. Asian Journal of Plant Sciences, 8, 562-565.

Sharma, M., Panwar, N., Arora, P., Luhach, J., \& Chaudhry, S. (2013). Analysis of biological factors for determination of air pollution tolerance index of selected plants in Yamuna Nagar, India. Journal of Environmental Biology, 34, 509-514.

Shao, F., Wang, L., Sun, F., Li, G., Yu, L., Wang, Y., et al. (2019). Study on different particulate matter retention capacities of the leaf surfaces of eight common garden plants in Hangzhou, China. Science of the Total Environment, 652, 939-951.

Sharma, S., Zhang, M., Ansika, G., J., Zhnag, H., \& Kota, S.H. (2020). Effect of restricted emissions during COVID-19 on air quality in India. Science of the Total Environment, 728, https://doi.org/10.1016/j.scitotenv.2020.138878.

Sjöman, H., Morgenroth, J., Sjöman, J. D., Sæbø, A., \& Kowarik, I. (2016). Diversification of the urban forestcan we afford to exclude exotic tree species? Urban Forestry and Urban Greening, 18, 237-241.

Solazzo, E., Cai, X., \& Vardoulakis, S. (2008). Modelling wind flow and vehicle-induced turbulence in urban streets. Atmospheric Environment, 42, 4918-4931.

Sulaiman, F. R., \& Hamzah, H. A. (2018). Heavy metals accumulation in suburban roadside plants of a tropical area (Jengka, Malaysia). Ecological Processes, 7(28). https:// doi.org/10.1186/s13717-018-0139-3

Takahashi, M., Feng, Z., Mikhailova, T. A., Kalugina, O. V., Shergina, O. V., Afanasieva, L. V., et al. (2020). Air pollution monitoring and tree and forest decline in East Asia: A review. Science of the Total Environment, 742, https:// doi.org/10.1016/j.scitotenv.2020.140288.

Tiwary, A., Morvan, H. P., \& Colls, J. J. (2005). Modelling the size-dependent collection efficiency of hedgerows for ambient aerosols. Journal of Aerosol Science, 37, 990-1015.

Tiwary, A., Reff, A., \& Colls, J. J. (2008). Collection of ambient particulate matter by porous vegetation barriers: Sampling and characterization methods. Journal of Aerosol Science, 39, 40-47.

Tiwary, A., Williams, I.D., Heidrich, O., Namdeo, A., Bandaru, V., \& Calfapietra, C. (2016). Development of multifunctional streetscape green infrastructure using a performance index approach. Environmental Pollution, 208, 209-220.

Tomson, M., Kumar, P., Barwise, Y., Perez, P., Forehead, H., French, K., Morawska, L., \& Watts, J. F. (2021). Green infrastructure for air quality improvement in street canyons. Environment International, 146, . https://doi.org/10. 1016/j.envint.2020.106288

Tong, Z., Baldauf, R. W., Isakov, V., Deshmukh, P., \& Zhang, K. M. (2016). Roadside vegetation barrier designs to mitigate near-road air pollution impacts. Science of the Total Environment, 541, 920-927.

Tripathi, A. K., \& Gautam, M. (2007). Biochemical parameters of plants as indicators of air pollution. Journal of Environmental Biology, 28(1), 127-132. 
Thawale, P. R., Babu, S. S., Wakode, R. R., Singh, S. K., Kumar, S., \& Juwarkar, A. A. (2011). Biochemical changes in plant leaves as a biomarker of pollution due to anthropogenic activity. Environmental Monitoring and Assessment, 177(1-4), 527-535.

van Leeuwen, E.S., Nijkamp, P., and Vaz, T.N. 2010. The multifunctional use of urban greenspace. International Journal of Agricultural Sustainability 8(1-2):20-25.

Vilcia, C., \& Sosea, C. (2019). A GIS-based analysis of the urban green space accessibility in Craiova city, Romania. Geografisk Tidsskrift-Danish Journal of Geography, 120(1), 19-23.

Wang, L., Gong, H., Liao, W., \& Wang, Z. (2015). Accumulation of particles on the surface of leaves during leaf expansion. Science of the Total Environment., 532, 420-434.

Wang, F., Zeng, B., Sun, Z., \& Zhu, C. (2009). Relationship between proline and $\mathrm{Hg} 2+$-induced oxidative stress in a tolerant rice mutant. Archives of Environmental Contamination and Toxicology, 56, 723-731.

Waser, N. M., Price, M. V., Casco, G., Diaz, M., Morales, A. S., \& Solverson, J. (2017). Effects of road dust on the pollination and reproduction of wildflowers. International Journal of Plant Sciences, 178, 85-93.

Wolfe, M. K., \& Mennis, J. (2012). Does vegetation encourage or supress urban crime? Evidence from Philadelphia, PA. Landscape and Urban Planning, 108(2-4), 112-122.

Woo, S. Y., Lee, D. K., \& Lee, Y. K. (2007). Net photosynthetic rate, ascorbate peroxidase and glutathione reductase activities of Erythrina orientalis in polluted and nonpolluted areas. Photosynthetica, 45, 293-295.

Yadav, R., \& Pandey, P. (2020). Assessment of air pollution tolerance index (APTI) and anticipated performance index (API) of roadside plants for the development of greenbelt in urban area of Bathinda City, Punjab, en. Bulletin of Environmental Contamination and Toxicology, 105(6), 906-914.

Yazid, A. W. M., Sidik, N. A. C., Salim`, M. S., \& Saqr, K. M. (2014). A review on the flow structure and pollutant dispersion in urban street canyons for urban planning strategies. Simulation. https://doi.org/10.1177/ 0037549714528046.

Young, N., Kadykalo, A. N., Beaudoin, C., Hackenburg, D. M., \& Cooke, S. J. (2021). Is the Anthropause a useful symbol and metaphor for raising environmental awareness and promoting reform? Environmental Conservation. https://doi.org/10.1017/S0376892921000254

Zhang, P.-Q., Liu, Y.-J., Chen, X., Yang, Z., Zhu, M.-H., \& Li, Y.-P. (2016). Pollution resistance assessment of existing landscape plants on Beijing streets based on air pollution tolerance index method. Ecotoxicology and Environmental Safety, 132, 212-223. https://doi.org/10.1016/j. ecoenv.2016.06.003

Zhong, J., Cai, X. M., \& Bloss, W. J. (2016). Coupling dynamics and chemistry in the air pollution modelling of street canyons: A review. Environmental Pollution, 214, 690-704.

Zowalaty, M. E., Young, S. G., \& Järhult, J. D. (2020). Environmental impact of the COVID-19 pandemic - a lesson for the future. Infection Ecology \& Epidemiology, 10(1), 1768023. https://doi.org/10.1080/20008686. 2020.1768023

Publisher's Note Springer Nature remains neutral with regard to jurisdictional claims in published maps and institutional affiliations. 